\title{
Expression and Emotion: Cultural Diplomacy and Nation Branding in New Zealand
}

Research thesis INTP 595

Submitted in partial fulfilment of the requirements of a Masters of International Relations

School of Political Science and International Relations

Victoria University of Wellington

March 2011

Katherine MacDonald 
Thank you to Dr David Capie for his support and guidance throughout this thesis and to Dr Robbie Shilliam and Dr Fiona Barker whose classes and discussions gave me inspiration and interest in the topic.

Thanks also to Matewai Tukapua and Andrew Gillespie for all their help and to Brendan Quinlivan for his friendship and willingness to explain the intricacies of cultural diplomacy to me.

And, finally, thank you to Emma and Teresa - I could not have done this without your love, laughter, understanding and support. 


\section{TABLE OF CONTENTS}

Introduction

1. The Forms of Soft Power

Public Diplomacy

Cultural Diplomacy

4

Nation Branding

Propaganda

Conclusion

2. "The Nation's Expressive Life": Using Culture to Foster Mutual Understanding

History

Current Cultural Diplomacy

Elements and Examples

Conclusion

3. The Asset of Emotional Capital: Creating an Image of New Zealand

The New Zealand Brand

National Identity

4. Discussion of Cultural Diplomacy and Nation Branding in New Zealand

Conclusion 


\begin{abstract}
States need to be recognised by other states to be legitimate and diplomacy is the way in which states represent their interests overseas. Cultural diplomacy is an important part of this diplomacy as it allows states to present their culture internationally and use it to build and maintain relationships that will be of value. Historically, cultural diplomacy has been a long term project, and the benefits to the state are not always immediate. In recent years, the more short term and immediate benefits of nation branding have become popular with states. Nation branding allows a state to promote itself and its products, resulting in quick and often very profitable economic benefits to the country. Like cultural diplomacy, nation branding draws heavily on the culture and imagery of the nation and uses it to gain an advantage.
\end{abstract}

This thesis looks at New Zealand's cultural diplomacy programmes and the very successful 100\% Pure New Zealand nation brand. It looks at the way in which the cultural diplomacy programme meets New Zealand's aims and is able to build long term relationships, promote understanding and protect its cultural sovereignty, and examines the way in which the new Zealand nation brand has managed to build such a distinctive image and attract customers. The thesis argues that the traditional long term cultural diplomacy is beginning to be changed as economic aims take precedence and it discusses some implications of this for New Zealand. 


\section{INTRODUCTION}

This thesis looks at New Zealand's cultural diplomacy and nation branding to see how the New Zealand government uses them to achieve its foreign policy aims. It starts by looking at cultural diplomacy, nation branding, public diplomacy and propaganda to find definitions for the discussion of cultural diplomacy and nation branding. These definitions are then applied to the New Zealand context to see how cultural diplomacy and nation branding are used by the New Zealand government and the thesis discusses how, in recent years, the two different strands of soft power have grown closer together. The final chapter looks at whether the evidence backs up this view, and what implications this may have for New Zealand's foreign diplomacy.

For any state, being recognised as legitimate by the other states is vital. This legitimisation comes from a number of factors, including having the mandate from the domestic population to conduct relationships within the international arena. In order to do this successfully, a state must have a sense of what it wishes to portray to the outside world, and what it wishes to gain from the interaction. In the past, relationships between states were built by finding common ground and building long term relationships. In recent years, this has changed and more short term goals are being sought by nations to fulfil economic purposes.

A state, regardless of its aims, has a foreign policy, which is the substance, aims and attitudes of its relations with others. Diplomacy is one of the instruments employed to put these aims into effect and the main role of diplomacy is negotiation and representing the state's interests overseas. Diplomats must manage relationships, identify common interests with other states and uphold the rules and procedures which regulate the international system (Evans, 1998 pp 128-129). States operate in an environment where maintaining relationships with other states is vital for their security.

Culture has always been a part of a state's foreign policy. Culture has been used by countries to showcase their society and their power for centuries (Bound, 2007, p. 15). Many countries have long had outposts overseas where they display their culture, teach their language and encourage the populations of other countries to get to know them. Culture can communicate what is important to a country and show others the values and beliefs that are important to the state. 
In the past, culture was the common language that elites talked, a neutral ground for the representatives of different states to meet on and discuss issues. Education opportunities were provided to the sons and daughters of the elite, creating a system where the rulers of nations had bonds and relationships that reinforced the status quo. These relationships did not have an immediate effect, and nor were they intended too. Their purpose was to create a climate where the future leaders of one country had a relationship with your state and an understanding of the values that you lived by. The benefits to your state would come in the future, making cultural policy a more long term exercise.

In recent times, however, these educational and cultural exchanges have ceased to have the same importance in cultural diplomacy. The internet has created a world where cultures meet and mix and reform easily and constantly and states are increasingly finding that they need to reaffirm their sovereignty (Mark 2008 p. 30) to stop their cultures being swamped or changed by access to other cultural outputs (Bound, 2007, p. 9). As Mark says, "a state's international cultural mission now involves a more active role in protecting and developing national culture" (Mark 2008, p. 30). A long term approach does not work in a world where things change in an instant - a state's cultural identity needs to be strong and constantly reinforced and revitalised, otherwise it is swamped and can be lost. A culture is still the set of values which underpins a nationbut it is also the shorthand marker that other states use to understand you. In a world of sound bites and logos, states have had to market themselves in a similar way to ensure they are not left behind.

Areas such as finance and culture, which used to be the preserve of states, are under attack from the mass communication revolution, and from the many non-state actors now in the world (Mark 2008, p.60). Gaining an economic advantage for your country and reinforcing its identity in an increasingly homogenised world has become the focus of public and cultural diplomacy. Soft power - or having the ability to persuade others by using your culture, values and ideas (Nye in Solter, p. 3) - is becoming more important to states. Soft power is a key element in foreign policy because it allows your state to attract others, set the agenda and frame the issues (Fan 2008, p. 148).

Soft power comes from the attractiveness of a nation's values, culture and policies and it causes people to act through co-operation rather than coercion. In an information society, soft power becomes more important. Many of the world's peoples have easy and instant access to all sorts of information and many of them have the ability to influence their governments' positions. Cultural and public diplomacy, and in more 
recent years, nation branding, are three closely linked and often interchangeable concepts that seek to use soft power to extend a state's foreign policy goals.

This thesis attempts to answer the question: are these differing forms of soft power different to one another and, if so, how different are they? The thesis's argument is that, while the definitions are often confused, there are two clear strands of soft power that a state needs in today's world: the more traditional strand called cultural diplomacy; and a newer, more simplistic strand called nation branding. Each fills a different niche in the world of public diplomacy, and each is needed by a state which wishes to ensure economic advantages for itself. Further, the thesis argues that, certainly in New Zealand, the two strands are coming closer together, and economic goals are starting to over ride the more traditional long term relationship goals of cultural diplomacy. 


\section{CHAPTER ONE THE FORMS OF SOFT POWER}

This chapter will look at the forms of soft power that governments use: public diplomacy, cultural diplomacy, nation branding and propaganda and attempt to find a working definition for them. Public diplomacy is an overarching term that includes the full gambit of strategies available to a government to win the hearts and minds of foreign audiences. Cultural diplomacy is a subset of this, and is more concerned with the communication between governments and officials, specifically in the area of culture. Nation branding, on the other hand, is less concerned with diplomacy and is more about marketing and gaining economic benefits for all the businesses under the broad umbrella of the nation brand. Finally, the chapter looks at propaganda, because soft power strategies can run the risk of becoming little more than propaganda if they are used in a clumsy way.

Later in the thesis, these definitions are used to analyse New Zealand's cultural diplomacy and nation branding programmes to see how the two work together, whether they are compatible and how they help New Zealand meet its aims as a state.

\section{PUBLIC DIPLOMACY}

\section{Definitions}

Views of what public diplomacy is differ markedly. In general, public diplomacy is about using public opinion in other countries to create a good impression of your state in their eyes. States do this by using their values and distinct attributes to appeal to the values of the foreign audience. If the population is won over, a state may be able to leverage this goodwill to gain some benefit for the state's foreign policy goals.

Schneider says public diplomacy is comprised of everything a nation does to explain itself to the world (Schneider, 2004, p. 1); Van Ham calls it a strategy of appealing to the core values of foreign audiences (van Ham 2008, p. 135) and Leonard says it should be about building relationships by understanding other cultures and finding areas of commonality (Leonard 2002, p. 50). 
Traditional diplomacy is concerned with the interactions that take place between governments, whereas public diplomacy is about targeting sectors of foreign publics in order to develop support for strategic goals (Ross, 2002, p. 75). Cowan and Cull define public diplomacy as "an international actor's attempt to advance the ends of policy by engaging with foreign publics" (Cowan and Cull, 2008, p. 6), while Hans Tuch (Tuch, quoted in Potter, 2002, p. 3) says public diplomacy is the communication that a government has with foreign publics to try and gain understanding for its ideas, values, culture and national goals and policies.

By using a range of means and instruments, governments can cultivate public opinion in other countries, hopefully managing to convince these foreign populations can influence their governments to change their stance towards your nation (Szondi 2008, pp 6-7).

Public diplomacy has two sets of goals: firstly, to communicate your state's foreign policy overseas and secondly, to try and develop an understanding and appreciation of

your society in other countries (Ross, 2002, pp 76-80). In the short term goals, your state attempts to shape overseas opinion abroad to be favourable to the policy of your government; whereas the long term strategy is to familiarise people abroad with your country and its citizens (Ryniejska-Kieldanowicz, 2005 p. 2).

\section{Changes in recent years}

There have been a number of changes in public diplomacy in recent years. The most obvious has been the object of the diplomacy: in previous years, the objective of public diplomacy was to get governments of other nations to change their policies to benefit your state. More recently, public diplomacy has begun to concentrate solely on the people, and attempting to create a positive environment among them for your state's foreign policy and national goals (Szondi, 2008, p. 7). Global media has created a more aware and activist society, making public opinion more important to governments (Potter, 2002, p. 5).

Public diplomacy is based on a complex relationship between the government, the media and public opinion (Gilboa, 2008, p. 62). Increasingly, actors and the media are engaged in creating frames that reach the public and influence public opinion (Gilboa, 2008, p. 64). In this context, public diplomacy is all about knowing how to create frames that 
resonant with other societies and in other countries - influencing the elites and media in a target state (Gilboa, 2008, p. 65).

Leonard says that, for these goals to be achieved, public diplomacy needs to deal with communication on day to day issues and treat foreign audiences as they would a domestic audience. Secondly, governments need to communicate strategically and manage the overall perceptions of their countries. Finally, governments need to develop lasting relationships with important individuals through scholarships, training and seminars (Bound, 2007, p. 24).

Jian Wang says that public diplomacy needs to promote a country's national goals and policies; communicate a nation's ideas and values; and build common understanding and relationships (Bound, 2007 pp 25-26). Of these, the last two can be carried out by nonstate actors and, Demos argues, cultural organisations, using culture, can operate on these levels for the government (Bound, 2007 p. 26).

Mark Leonard outlines four purposes for public diplomacy in 2002 (Bound, 2007, pp 2324): increasing familiarity, or making people think about your country and up-dating their image of it; increasing appreciation, or creating a positive view of your country and getting others to see the issues from your point of view; engaging people to see your country as a place they want to visit or study and whose products they want to buy; and influencing people's behaviour by getting companies to invest, getting politicians to be your ally, and getting public support for your nation. These purposes are very similar to the idea of nation branding.

\section{Conclusion}

Public diplomacy is the art of using a state's ideals and values to appeal to the values of a foreign audience. States can gain benefits and advance their foreign policy goals if the foreign population is attracted by the state and, in turn, influences its own government in favour of your state.

\section{CULTURAL DIPLOMACY}

Cultural diplomacy is called by a number of different names, and it is difficult to differentiate it from public diplomacy. Below, definitions of cultural diplomacy and how 
it differs from public diplomacy are examined. In Chapter two, New Zealand's cultural diplomacy is looked at in depth and the elements explored in more detail.

\section{Definitions}

Public diplomacy is about communication with foreign publics and it has a wide range of interests, whereas cultural diplomacy concentrates on culture and is the communication with other governments and officials (Mark, 2008, pp 39-65). Culture is generally defined as "the arts and other manifestations of human intellectual effort" (Oxford dictionary) but it is generally regarded to be wider than this in cultural diplomacy, encompassing sport, science, architecture and popular culture. The most widely used definition of cultural diplomacy is Milton C. Cummings' 2003 definition of it as "the exchange of ideas, information, art and other aspects of culture among nations and their peoples in order to foster mutual understanding" (Cummings in Gregory 2005, p. 11).

The Arts Industries Policy Forum defines cultural diplomacy as the "domain of diplomacy concerned with establishing developing and sustaining relations with foreign states by way of culture, art and education."(The Arts Industries Policy Forum, p. 1). Fox, quoted in Mark, says cultural diplomacy implies the involvement of government in the business of projecting the nation's image abroad, "the business of winning friends and influencing people" (Mark, 2008 p. 25).

The Demos group says cultural diplomacy is not easy to define but they take it wider to include things of mass cultural appeal - such as sport, popular culture and science (Bound, 2007, p. 16). They argue that cultural diplomacy has traditionally been the relations between elites, with culture as the universal language they spoke. Now, culture is created by the masses for the masses and any sort of culture is easily and frequently accessed and enjoyed by a large number of people (Bound, 2007, p16). Cultural diplomacy is the "nation's 'expressive life' but it also incorporates the exchange of values and overarching ideas and its value is in its ability to initiate and sustain a relationship about trust and mutual respect" (The Arts Industries Policy Forum, pp 1;13).

Gregory says diplomats assume cultural diplomacy will take time and is not a short term fix (Gregory, 2005, p. 11): long term involvement is critical to cultural diplomacy (Cultural Diplomacy: Recommendations and Research, 2004). 


\section{Changes in recent years}

Belanger says foreign policy can no longer just promote an existing culture abroad (Belanger p. 166) - it now needs to actively protect and develop its culture and use it to gain an advantage for the state. Mark sums this up when he says that, simply put, cultural diplomacy is "the deployment of a state's culture in support of its foreign policy goals or diplomacy" (Mark 2010 p. 1). Culture must not only foster understanding among peoples but it also needs to provide opportunities for co-operation and trade (Feigenbaum 2001, p. 25).

Using culture to advance the interests of the state is an old idea (Bound, 2007, p. 15), although today's cultural diplomacy is markedly different to what it used to be. In today's world, issues are more complex and span countries and groups; there are more actors: state, sub-state and non-government; communications are faster and more freely available; and the domestic and the international frequently blur (Mark, 2008, p. 34). The fall of the Soviet Union and the bi-polar world has meant a growth in small nations, each constructing their own identities, and cultural factors increasingly play a part in how states define themselves (Bound, 2007, p. 17).

All these changes have meant that traditional diplomacy has had to change and as the work increases, more domestic actors are bought in to help undertake what used to be traditional diplomatic work (Mark, 2008, p. 36). These actors include ministries and agencies with specialist skills, such as science, education - and culture. These areas often provide economic benefits to the state, and, in the case of culture, are an integral part of the state's identity (Mark, 2008, p. 36). More and more, culture is a vital part of a state's diplomacy and its foreign policy.

\section{Central elements}

Cultural diplomacy is undertaken for a number of reasons. These can be domestic, such as the making and executing of cultural agreements overseas (Mark, 2008, p. 51) or to gain advantages for artists in your state, or can be more externally focussed such as presenting a state's image abroad, (Mark, 2008, p. 30), and enhancing mutual understanding (Marks, 2010, p. 4). As well as this, cultural diplomacy can be used to protect a nation's cultural sovereignty and showcase its identity (Mark, 2010, p. 6), especially in cases where it may seem to be under threat from larger or more ubiquitous 
cultures. This is seen in the case of France, which strongly defends its language and culture against foreign, often English speaking, cultural influences.

If successful, cultural diplomacy can do a number of things (The Report of the Committee on Cultural Diplomacy, 2005, pp 1-2). It can help create a foundation of trust with other nations which policy makers can build on to reach political, economic and military agreements. It can demonstrate your values and combat stereotypes of the nation and encourage people to give your country the benefit of the doubt since there is a presumption of shared interests. It can reach influential members of foreign societies who cannot be reached through embassy functions and create a neutral platform for contact. It can serve as a flexible, acceptable vehicle for approaching countries where diplomatic relations have been strained or are absent. It can reach all types of people and foster the growth of civil society. Finally, it can educate citizens of your country on the cultures of other countries. Many of these benefits are not economic, and are the result of a concerted, long term effort on the part of diplomats.

Below, the thesis looks at elements considered to be of importance to cultural diplomacy; the role it plays in promoting understanding between states; its use of national identity to create a stronger cultural sovereignty; advancing the national interests of the state overseas; and the way in which it complements more traditional diplomacy and foreign relations.

\section{Promote understanding}

Culture is a non-threatening, inclusive way of communicating with people. It is powerful because it is universal and is shared by all the peoples of the world: "culture has no frontiers. It is a manifestation of human genius and achievement and is charged with symbolic meaning. Therefore, it can be seen to belong to everyone, regardless of country of origin" (Telles Ribeiro, 2008, p. 5). Different peoples and groups can meet as equals in a cultural setting and culture has a worldwide appeal that transcends national differences. Often, enemies in a more traditional sense can enjoy the music or art of each other's country.

This universality makes culture a good vehicle to promote understanding because it creates a level playing field where everyone can put aside their differences and meet. Cultural diplomacy can take this universal love of the arts and use it to foster mutual understanding between nations (Ryniejska-Kieldanowicz, 2005, p. 9) but to be effective, 
cultural diplomacy has to be sensitive to intellectual, religious, artistic and other nonpolitical developments (Mulcahy, 1999, p. 5).

It is easier for nations to work together if they have some understanding of one another, so cultural diplomacy must also understand the cultural norms and values of the target nation too, and try and understand the viewpoints in that society. Cultural diplomacy aims to develop a mutual understanding and, at the same time, combat ethnocentrism and stereotyping (Mulcahy, 1999, p. 3). If a country has a bad reputation or is internationally unpopular, cultural displays can help show that the views of the government are not held by the whole nation and it can challenge the popular perceptions that may be held about that nation (Bound, 2007, p. 26). Cultural diplomacy builds this understanding by attempting to familiarise other people with the country and its culture and hopefully creating a positive image of the country through this familiarisation (RyniejskaKieldanowicz, 2005, p. 8).

Exchanging ideas and demonstrating your culture to others is at the heart of this exchange. Schneider (Schneider, 2003, p. 3) provides a number of ways in which cultural diplomacy can work to familiarise people with a country's culture. Cultural diplomacy is creative, flexible and opportunistic and it communicates a nation's values to another nation. It opens doors between diplomats and their host country and provides another dimension to the official presence in the host country. Importantly, it is part of a long-term relationship.

All of these things will promote your country to the target country so it understands your viewpoint; and will also let the target nation know that you understand and respect its viewpoint too.

\section{Expression of cultural sovereignty}

Globalisation has meant that some countries feel their cultural differences have been subsumed and lost in the cultural products of richer, western countries, particularly the US. Modern technology means that culture from other nations is easily disseminated around the globe, which can have a devastating impact on the culture of smaller nations.

This loss of cultural sovereignty can be disturbing for states as culture not only defines who a nation is, but it also generates jobs and income to the nation. Losing your cultural identity can be a serious loss, as a nation's idea of itself is best represented through its 
cultural activities (The Report of the Committee on Cultural Diplomacy, 2005, p.12). Mulcahy, quoted in Feigenbaum, says "culture is an expression of national identity and as such, is to be promoted and protected as a public responsibility" (Feigenbaum, 2001, p. 21).

Cultural diplomacy is one way in which a nation's cultural sovereignty can be maintained. If culture is used to advance foreign policy goals, then a state has a vested interest in investing in domestic culture to have something to market and showcasing culture to international audiences gives culture some worth domestically. Mark (Mark, 2010, pp 11-12) discusses the case of Canada and how it has created the protection of Canadian values and culture as the third pillar of its foreign policy. It does this for three reasons: to promote Canadian culture to generate jobs and make money; secondly, to support Canadian artists against foreign competition; and finally, to project a strong image of Canada's identity and sense of who it is.

A state protects its cultural sovereignty by encouraging culture domestically, but also by seeking cultural exemptions in trade agreements or gaining access to telecommunications networks - going much wider than the old role of simply promoting culture abroad (Belanger 1999, p. 678). Culture is now a product like any other, and states have an obligation to protect it and advance it where they can.

\section{Advance national interests}

As discussed above, cultural diplomacy programmes can advance the domestic interests of the nation. This is clearly seen in the current education climate where attracting students to your country brings money as well as cultural capital into your state. Equally, the many cultural agreements signed between nations now are economically valuable to both states.

Until quite recently, cultural diplomacy consisted of funding artists' tours or promoting the study of the country's language and culture abroad, but now it is more concerned with dealing with the challenges the state's unique identity has in the face of globalisation (Belanger, 1999, p. 677). Belanger says this has rewritten the relationship between cultural diplomacy and foreign policy as the state's mission is no longer just to promote its culture abroad - protecting and developing the state's culture is now the national interest (Belanger, 1999, p. 678). 
At times when a state's diplomatic or political relationship with another country is strained, cultural ties may be one of the only lines of communication between the two states. Cultural organisations and groups can keep communications open and relationships going until the diplomatic issues have been worked out (Bound, 2007, p. $55)$.

Culture can also be used to renegotiate people's perceptions of a state. Demos discusses China and the way in which it deliberately uses its ancient culture to give tourists and visitors a framework within which to view China. This image allows people to explore China and its culture without having to confront contemporary issues (Bound, 2007, p. 59). This is a useful tool for states which may have a negative image - culture is a way by which other values and attitudes of the nation can be shown to foreigners.

\section{Complements diplomacy}

Schneider says cultural diplomacy sits within the broader context of public diplomacy (Schneider, 2004, p. 1), while Szondi says cultural diplomacy is strictly connected to a country's government and achieving its foreign policy objectives (Szondi, 2008, p. 7). Brazilian Ambassador Telles Ribeiro, talking at the SIFA Ambassador Talks Program in Bangkok in 2008, called cultural diplomacy "nothing more, nothing less, than cultural relations put at the service of foreign policy" (Telles Ribeiro, 2008, p. 3).

Public and cultural diplomacy are very similar, but cultural diplomacy is concerned solely with culture, in all its guises. It can complement traditional foreign policy by showing others the educational and cultural attainments of the society (Mulcahy, 1999, p. 5) and creating a positive atmosphere around the nation whose culture it promotes (Telles Ribeiro, 2008, p. 4).

Diplomacy has a political agenda in mind but cultural diplomacy goes beyond that - it promotes culture but it also helps create a favourable atmosphere which often paves the way for other agendas (Telles Ribeiro, 2008, p. 5).

\section{Conclusion}

Cultural diplomacy is a very long investment with no foreseeable dividends (Telles Ribeiro, 2008, p. 4). This is the strength of cultural diplomacy: it uses the native strengths and resources of the nation's creative population and uses them to present a 
view of the nation that is not inherently political or for any overt gain. Culture is there to tell the nation's story and provide enjoyment - its purpose is to find common ground and build relationships. It may take many years to result in any benefits for the nation, but it doesn't matter because the purpose is mutual understanding and not a short term, one-off gain.

Cultural diplomacy is the way in which a state uses arts and culture to find common ground with and maintain relationships with foreign states. States must understand the value of their unique culture and have a clear understanding of who they are, and then be able to communicate this clearly to other states.

Cultural diplomacy, unlike public diplomacy, tends to be communication between officials and governments, and is not necessarily aimed at the general public.

Increasingly, however, this is becoming blurred, and the audience to be won over by culture includes the general population.

\section{NATION BRANDING}

Nation branding, one of the newer forms of soft power, shares a number of similarities with public and cultural diplomacy. Like public diplomacy, it is concerned with using values and national attributes to win over a foreign audience. Like cultural diplomacy, nation branding draws heavily on the nation's culture to differentiate itself from others. Below, nation branding is defined, including a look at what elements are important, and in Chapter three, New Zealand's 100\% Pure brand is looked at in depth.

\section{Definitions}

In marketing, brands are about gaining customer recognition and using this increased recognition to build financial value (Pure As; Celebrating 10 Years of 100\% Pure New Zealand, p. 21). A brand must use the tools it has to influence audiences to favour the products. Branding can do this effectively by giving the nation or product an emotional dimension with which people can identify (Gilboa, 2008, p. 67). To work, brands need to combine customer service, product performance, attitudes, logos and advertising to create a sense of value in the mind of the customer (Harnish Patel, in Pure As;

Celebrating 10 Years of 100\% Pure New Zealand, p. 21). 
Nation branding is about how the nation as a whole presents itself to other nations (Anholt, 2006, p. 271). Nations gain customer recognition by building positive images of their nation in the minds of others and creating a receptive environment for the brands to compete in (Gudjonsson, 2005, p. 286). To ensure that people are making a choice that benefits your brand, a nation must first differentiate its brand to make it stand out. This is done by creating a good image of the nation, using the country's unique culture and identity, and by carefully choosing values and images that will appeal to the target audience. Brands tap into imagery - and this imagery comes from the pool of symbols and stereotypes that the nation uses to define itself (O'Shaughnessy, 2000, p. 58). A nation also needs to make sure it manages the perceptions others have of it, minimising any negative stereotypes or views and maximising the positive views.

Once the brand has been built and put in the market place, nations must use their resources to create markets and attract the sort of investment they want. Nation branding is all about creating reputational capital at home and abroad (Szondi, 2008, p. 5). Gudjonsson says nation branding is "when a government or private company uses its power to persuade whoever has the ability to change a nation's image" (Gudjonsson, 2005, p. 285).

As economies have become more globalised, nations have had to find ways of making their products different from the competition and more desirable to domestic and international consumers (Dinnie, 2008, p. 14). One way to do this is by utilising the nation's existing reputation and identity to gain a competitive advantage - a national identity is a strong way to capture the attention of overseas markets and investors (True, 2006 , p. 80). Branding is the way nations differentiate themselves globally, attract investment and create markets for their products (Dinnie, 2008, p. 139).

\section{Central elements}

Below, the aspects necessary to nation branding are discussed, including differentiating the brand, building a positive image, managing perceptions and creating new markets and attracting investment.

\section{Differentiating the brand}

Many countries offer the same product: stable democracy, educated population, innovative ability, beautiful scenery, and countries must be able to differentiate 
themselves in this market (van Ham, 2008, p. 129). Morgan et al. believe that the way a country can differentiate itself is by managing to create an emotional tie in the consumer so they feel close to the destination (Morgan, 2002, p. 336). Once this emotion has been achieved, the brand needs to develop some strong associations that are unique and which show a point of difference between this brand and the other brands (Morgan, 2002, p. 337).

Nation branding attempts to harmonise policy, people, sport and culture, products, tourism, trade and investment promotion and talent recruitment (Anholt, 2006, p. 271). A country offers a large number of images, folklore, history and symbols - that is, its identity - and the key is to exploit the right fragments from this identity to create a successful brand (O'Shaughnessy, 2000, p. 58). A successful brand is one that the nation itself believes in; and to be different to everyone else's brand, the imagery has to have something that sets it apart from other brands.

The problem with basing a brand on a nation's identity is that identity is very fluid. The image of a nation can change easily and different parts of it come into focus at different times. The same country can have multiple meanings - Italy for instance can be good food; stylish clothing; the Mafia; Roman ruins; Renaissance art; volubility and laziness (O'Shaughnessy, 2000, p. 58). These images can co-exist, or they can have different meanings to different people. Class, gender, age - demographics can all change how a country is viewed, and thus how its brand is perceived.

\section{Building positive images}

Nations have a number of assets that they can call on when branding: Dinnie breaks them down into internal assets, consisting of innate and nurtured features and external assets, which can be vicarious or disseminated (Dinnie, 2008, pp 67-72). These internal assets work towards building a positive image of the nation, while the external assets are more concerned with managing the image of the nation.

The innate features are the enduring elements of a nation such as landscape, iconography and culture (elements of national identity) while the nurtured aspects are the conscious attempt to create a healthy environment and buy-in for the brand. This can include getting the internal population of the nation to "live the brand"; making sure support of the arts and culture is strong; and encouraging loyalty to the nation's brand and products from domestic consumers and overseas friends (Dinnie, 2008, pp 69-71). 


\section{Culture, national identity and landscape}

Van Ham says that while soft power is about influence and control, nation branding is about identity formation (van Ham, 2008, p. 131). To have a successful brand, the domestic population must believe in the brand and model it, and one of the best ways to ensure they do is by having a brand that reflects what the nation thinks of as its national identity. Hatch and Schultz (quoted in Stock, 2009, p. 120) say national identity is important because "who we are cannot be completely separated from the perceptions others have of us and we have of others". Olins has argued that, increasingly, branding is becoming about identity management and how a nation perceives itself (Olins in van Ham, 2008, p. 131).

Nations must find ways of differentiating themselves from others in the minds of others. This can be done through using the country's unique culture, national identity and/or landscape. People need to make sense of the world around them and one way of doing this is to define themselves into a group, with a set of agreed values and goals. The collective group must construct itself in some way that defines it accurately and to the agreement of all the group; and which differentiates it from other, similar groups.

National identity is a combination of factors, including myths, history, and a common homeland and it is symbolised through emblems such as flags, costumes, languages and landscapes. Many of these images and symbols are cultural in origin (O'Shaughnessy, 2000, pp 57-58). Culture is a central component of national identity, and national identity is a large and important part of nation branding (Dinnie, 2008, p. 137).

Dinnie believes that culture gives a nation's brand its true essence (Dinnie, 2008, pp 118120 ) and nations use their national identity to draw on deep cultural resources to provide the brand with emotional resonance (Dinnie, 2008, p. 14). Heritage, landscape and the arts are central to a country's culture and how it is portrayed and viewed externally (Dinnie, 2008, pp 147-149). Nations, he argues, have always incorporated cultural expressiveness in their brands through organisations such as the Goethe Institute (Germany) and the British Council (Dinnie, 2008, p. 148) - in other words, through the use of cultural diplomacy.

The problem with relying on national identity and culture to make the brand is that identity is an invented and is often a very mutable concept. A brand needs to choose the 
right image for the brand's aims and objectives: and a nation needs to take care that the image chosen does not supersede the variety and richness of a proper national identity.

Support from the domestic population

To work, a brand must have support from the nation's own population - nation branding is successful when the brand is lived by the citizens (Szondi, 2008, p. 5). Aronczyk says:

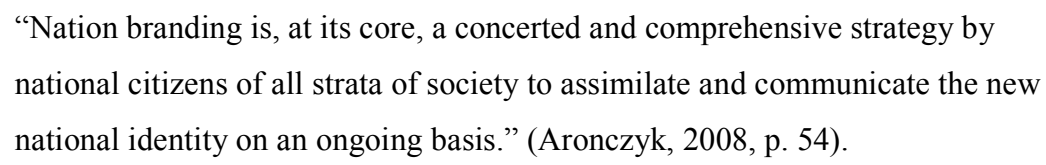

Wally Olins (quoted in van Ham, 2008, pp 131-2) has argued that as global companies have grown and become multinational, they have lost their sense of purpose. Branding is one way that the company can unite all the employees together, giving them coherence, a sense of togetherness and a purpose. Branding is as much about uniting the internal group as about attracting the external group, as citizens who are behind the brand will act as brand ambassadors (Szondi, 2008, p. 12). Aroncyzk says that nation branding serves a powerful domestic purpose by convincing people that the government is acting in their best interests - they see the nation logo everywhere and know it is all for them (Aronczyk, 2008, p. 44).

\section{Using values that appeal to others}

When creating the brand, a nation needs to define its values and decide what image it wants to project. If a nation does not actively define itself, it will be defined by myths, stereotypes and views, and these may not always be positive or helpful to the brand (Dinnie, 2008, p. 150). There are a number of social and cultural mores that exist in a nation, creating the core values of the nation. A brand can draw on these and use them to build the brand. Good brands work because the population, who are the people delivering the experience, unconsciously model the values - because they are the values of their nation (de Chernatony in Dinnie, 2008, p. 16).

The branding nation must work out what values are important to the target audience and then find and portray those values in their nation brand (O'Shaughnessy, 2000, p. 63). When consumers choose a product, they are often making choices based on the lifestyle they want, the image they are looking to portray (Morgan, 2002, p. 337). A successful 
brand will make sure the values and lifestyle it portrays are attractive to its target audience.

\section{Managing perceptions}

Perceptions are very important to a brand. Nations have a number of assets that can be used to help with branding, including external assets. Dinnie calls these vicarious or disseminated assets (Dinnie, 2008, pp 67-72). Vicarious assets are experiences gained second hand, such as views of a country gained from media reports, films or literature often the views or stereotypes of the nation. Disseminated assets are those that are projected beyond the nation, such as brand ambassadors, the nation's diaspora people and brand exports (Dinnie, 2008 pp 71-73).

People hold different views of a country, drawn from different places, such as the performance of national sporting teams or knowledge of the art forms of the country (Dinnie, 2008, p. 47). Personal experience of a place can play a key role in how a person views a country, but there are other factors too, such as word of mouth stories from others or performance of products associated with the nation. Political or other newsworthy stories also influence the public's view (Dinnie, 2008, p. 47).

These things will have an impact on a brand and how the target audience receive it. To ensure a brand works, the producers must ascertain what views are in the minds of the audience and then work towards enhancing any positive views and minimising any negative ones (Dinnie, 2008, p. 47). As a brand can be fluid and consist of multiple parts, countries can choose to focus on areas that work for them, such as tourism, successful exports, notable sporting achievements or diaspora communities (Dinnie, 2008, p. 49). Diaspora communities are valuable as they can translate the nation's values into the language of the target nation and they can provide on the ground knowledge and understanding of the target market (Leonard, 2002, p. 55). Their loyalty to the 'old country' can also be tapped and used.

Countries and products often merge, creating what is called the country of origin effect. This means that a country is associated with its products - Germany with cars, Coca-cola with America, Nokia with Finland (van Ham, 2008, p. 129) - and can be invaluable for a nation brand. This association can work in several ways (O'Shaughnessy, 2000, pp 59 62) such as through conditioning, where a nation's products are associated with positive and persuasive images. Appealing to a feeling of solidarity also helps associate the 
product in people's minds because promoting a particular brand invites those who are peripherally associated with it to adopt this image and take on the attributes the brand represents. Finally, a nation can use association by exploiting the prestige of another nation - for example, by giving your whiteware a German name.

A brand can be derailed by a country's actions. It is more important to show than tell (van Ham, 2008, p. 141) - in other words, how a nation conducts itself on the world stage is central to how other countries perceive it. Buyers will always hold some view of the nation and they will buy accordingly. This can be due to a like or dislike of the nation, or a sense of how high the nation's reputation is. Both will affect the nation's image (O'Shaughnessy, 2000, p. 59). A brand can easily be destroyed if the political or cultural factors of the state are not in line with the brand perception (Gudjonsson, 2005, p. 286).

\section{Creating markets and attracting investment}

The challenge for a nation seeking to create a market for its brand is how it can make its brand stimulating and desirable, so that consumers want to experience the brand and the values it embodies (Morgan, 2002, pp 339-352). Audiences will favour a brand that they have an emotional connection with (Gilboa, 2008, p. 67). Consumers often rely on a shorthand when they buy a product - they make decisions about quality and worth of products without having to think about it because they have internalised the brand. A successful nation brand will personify the country on the international stage, and act as a shorthand for other nations (van Ham, 2008, p. 130).

Morgan et al (Morgan, 2002, pp 344-352) discuss a number of stages that are important in creating a brand to appeal to a market, such as establishing the core values of the brand, positioning the brand and harnessing the web.

The first stage in building a brand is to establish the core values of the nation and its brand, making sure they are relevant to the market and compare favourably with any competition (Morgan, 2002, p. 344). The values need to create an emotional relationship between the destination and the consumer (Morgan, 2002, pp 340-341). The brand needs to have emotional appeal and be a place that is seen as desirable and prestigious to visit Morgan et al call it "celebrity appeal" (Morgan, 2002, p. 342). 
The next phase is to define what the nation stands for and work out how this can be translated into a brand (Morgan, 2002, p. 345). The brand needs to have an emotional heart, teamed with more logical features and values (Morgan, 2002, p. 346).

Finally, a nation should use a range of ways of advertising the brand to get it out to the target audience. Interactive media, direct marketing, and events capitalization are very effective ways to advertise a brand (Morgan, 2002, p. 349).

\section{Conclusion}

Nation branding is a very one-dimensional exercise: it is the creation of a very simple but powerful image in order to sell. Its strength is that it is a user-friendly shorthand that, if done well, can be picked up and applied to a wide range of products.

Nation branding is the creation of a unique image which creates an emotional tie with the customer and convinces them to buy the nation's products. States build this image and gain their reputation by using internal features like natural resources, people, values, arts and culture to build a positive image of the nation, and external assets like other reports of a country, reputation, ambassadors and country products, to manage the image of the nation. Once established, states must position and market the brand.

In short, nation branding is a combination of the approaches states use to create a nation's distinctive image, then use it to create a sense of value in the mind of the audience.

The downside to nation branding is that, in a world where sound bites rule, the nation can run the risk of being reduced to one image only. To stop this, nations must be aware of what images they are creating and they must continually manage the brand. They must also be aware that the nation cannot afford to survive purely on its brand: there must be more that sits beneath. A nation is a vastly complex group of people, their histories, stories and values. It is always changing and growing, and this essential component of a nation should not be allowed to wither or be lost because the focus is on the economic worth of the nation brand. 


\section{PROPAGANDA}

Forms of soft power can easily become propaganda, or be perceived as propaganda by other nations. Propaganda is the deliberate attempt to persuade people to accept a particular definition of a situation by manipulating factors in their personality or in their environment to change or mould their behaviour towards your desired end (Evans, 1998, p. 451).

Propaganda uses several techniques (Evans, 1998, p. 452). It simplifies issues, concentrates on things that mean something to the recipient, and sensationalises issues, arousing strong emotion in the audience. This can include using stereotypes.

\section{Propaganda and cultural or public diplomacy}

Public diplomacy is using public opinion in other countries to create a good impression of your state in their eyes. If the population is won over, a state may be able to leverage this goodwill to gain some benefit for the state's foreign policy goals. Cultural diplomacy is how a state develops and maintains rapport with foreign states by way of culture. To be successful, a state must first have defined its culture and then be able to communicate this culture to other governments and officials

The line between propaganda and cultural diplomacy is difficult, especially in the cases of some countries where converting other, antagonistic countries to their way of thinking seems to be the sole aim of the cultural diplomacy exercise. For example, early cultural policy for Americans was a reaction to communism - in an attempt to win the public opinion war, the US drafted everything in to the fight (The Arts Industries Policy Forum, 2005 p. 2) and Cowan and Cull say that the term public diplomacy was coined to liberate America's practice of exchanging international information from the term 'propaganda' (Cowan, 2008, p. 6). In cases where a mutual exchange of ideas is absent for the aims of the cultural diplomacy programme, propaganda is a more accurate description of the process than cultural diplomacy.

A number of authors have seen similarities between propaganda and public or cultural diplomacy. Leonard says "the term 'public diplomacy' is often a euphemism for propaganda" (Leonard, 2002, p. 50). The Arts Industries Policy Forum says that at its core, cultural diplomacy includes creative expressions, but it also tries to incorporate the exchange of values and overarching ideas (The Arts Industries Policy Forum, 2005 p. 1). 
It is not, therefore, purely culture but culture that has a certain propaganda value. The Survey of Cultural Diplomacy and US government (Cultural Diplomacy and the United States Government, pp 12-15) says that there is often a thin line between propaganda and the softer, two-way understanding side of cultural diplomacy.

Leonard believes that the only way countries can move public or cultural diplomacy beyond propaganda is if they make sure they understand their target audience; confront any hostility in the target audience towards the state; engage people emotionally; and prove their relevance to the target audience (Leonard, 2002, p. 51).

Mark makes the valid point that whether cultural and public diplomacy is propaganda will depend upon which definition of propaganda you use (Mark, 2008, p. 57). As most modern diplomacy involves some sort of two way communication and mutual learning, he argues that it is not propaganda. The Demos group also believe that cultural diplomacy, because it seeks to communicate, is more subtle and less intrusive than propaganda (Bound, 2007 p. 22).

Another argument against propaganda is that, while propaganda is related to cultural and public diplomacy and is the strategy of appealing to the core values of foreign audiences, it is less intrusive than propaganda (Van Ham, 2008 p. 135) and does not seek to narrow other people's minds. Mulcahy says cultural diplomacy is not propaganda because propaganda is direct. It is seeking to explain to overseas audiences what a nation is about. Cultural diplomacy, on the other hand, is more indirect and uses personal experiences to win people over. Rather than being told, overseas audiences are allowed to experience culture and decide for themselves whether they like it and agree with your message (Mulcahy in Feigenbaum, 2001, pp 30-31). Mark argues that "culture has an inherent honesty to it that could well thwart such efforts" (Mark, 2010, pp 4-5).

\section{Propaganda and branding}

Nation branding is the sum total of the strategies states use to find their unique image and utilise it to build financial value. Van Ham calls propaganda a "rather unsophisticated forerunner of place branding" (van Ham, 2008, p. 133). He contends that place branding, with its slogans, symbols and emotive identities is closely tied to propaganda.

Anholt, however, says that nation branding is "not government spin or propaganda" because it does not argue with people or try to change their minds - nation branding does 
not construct its reputation, it can only earn it (Anholt 2007, website). He defines propaganda as "attempting to manipulate perceptions directly" and believes that propaganda depends on a closed society and control over the sources of information reaching the target (Anolt, 2009, website). Very few societies are closed with the advent of globalisation, making propaganda very difficult in Anholt's view.

Propaganda and nation branding do seem similar: both use simplistic and emotionalised messages to win hearts and minds to a particular way of thinking. Both are deliberate attempts at manipulation and both aim at a very specific end outcome. The difference between propaganda and nation branding is that propaganda works in an insidious way to develop emotions. Nation branding is more open about its aims and the audiences are being manipulated in a way that is fairly transparent, with the option of opting out of receiving the message. The net gain of the nation branding manipulation too is different: if the branding works, the end result is a financial gain for the nation. The target does not actually lose anything or have to compromise their citizenship, values, beliefs or morals.

\section{CONCLUSION}

States have a duty to ensure the safety and well being of their nation. To do this, they must establish good relationships with other states and build links and form partnerships that will benefit their people.

Diplomacy, and in particular, public diplomacy, is the traditional ways in which states have done this, both by presenting the state's views overseas, and also by identifying areas of common interest and building relationships. States use their attributes to gain friends, create an appeal and find ways to facilitate the state's foreign policy goals.

Culture has long been the way in which states establish common ground and portray themselves. Culture is a non-threatening, universally appealing tool, and states could use it to communicate their values to others. In the past, elites often shared cultural values and norms: today, culture is used as something to distinguish your country and attract people to it. This is due to the growth of the internet and other mass communication tools which make the world more homogenous, but is also a result of countries seeking to define themselves and carve out individual niches. Increasingly, cultural diplomacy is less about the stage where the world's elites gather to make decisions against a congenial 
backdrop, and has instead become one of the tools by which states market themselves to a fast moving world.

Interestingly, globalisation could be said to increase the importance of a nation's unique identity as nations must now play up the distinctiveness of their countries in order to gain a competitive edge (True, p. 73) and create economic opportunities. The stronger and more appealing your image, the more value your brand will have, and the more financial value you will gain for your country. Soft power is no longer a tool to be used to show your state's appealing side: it has a harder edge as it is used to attract customers and sell your products.

I believe that, while the traditional public and cultural diplomacy have drawn closer to the new nation branding, there is room in the state's arsenal for both forms. Nations still need the long term benefits that cultural diplomacy brings, and they need to ensure that the pursuit of economic advantage for their state does not alienate the very friends cultural diplomacy has made them. The rest of this thesis will look at New Zealand's cultural diplomacy programmes and the nation brand it uses, and will analyse how closely the two are tied together and how each helps New Zealand in the international arena. 


\section{CHAPTER TWO \\ “THE NATION'S EXPRESSIVE LIFE": USING CULTURE TO FOSTER MUTUAL UNDERSTANDING}

Cultural diplomacy is the way in which a state uses its arts and culture to build and sustain long term relationships with foreign states. Its strength lies in its ability to take a long term view and work towards building relationships that are enduring. These relationships are built on a country's culture and identity, and thus mean something to the people, giving the relationships a sense of integrity.

With this definition, states that have successful cultural diplomacy programmes must have a clear understanding of what their nation's culture is. This means a state needs to have some way of identifying its cultural identity, and it must have the means of nurturing and promoting the culture internally and externally. If a culture is an integral part of the population, it is far more easily communicated to foreign states. The sharing of culture thus means that the state is sharing something that is an essential, unique and fundamental part of itself.

Beyond the use of culture, cultural diplomacy is the interaction between state officials and governments. It does not have to be aimed at the population of other states although increasingly, the general population is gaining a greater role in the domestic politics of states and is being targeted by cultural diplomacy.

This chapter looks at cultural diplomacy in New Zealand, primarily at the role of the Cultural Diplomacy and International Programme (CDIP). Also mentioned are some smaller international strategies run by agencies in the cultural sphere. The thesis has not attempted to look at whether New Zealand as a nation has a clear sense of its unique culture - for the purposes of discussion, it is assumed it does, that the state nurtures this culture, and that the population have internalised it enough to be able to model it.

In general, cultural diplomacy includes the following components: promoting understanding in foreign countries; the expression of national identity; pursuing domestic objectives; the protection of cultural sovereignty; and complementing traditional diplomacy. The chapter concludes by looking at these five elements of cultural diplomacy to see how they manifest in New Zealand's cultural diplomacy programme. 
The thesis's main interest, however, is in how New Zealand's cultural diplomacy fits the definition above and how it has developed over the years. The programme has gone from one that more closely fits the traditional definition of cultural diplomacy to one that is more economically focussed. This may be because of the growth of globalisation and neoliberalism, which has had an effect across the international sphere, but it may also be more domestic. In recent years New Zealand has gained a new government with a strongly stated economic agenda, and national identity, which was one of the last government's priority areas, is not a priority for the National government. The emphasis is on increasing the economy, with other traditional responsibilities of the state, such as negotiating and maintaining relationships, being subordinated to growing new markets. Domestically, there are signs that the model is slowly changing as an awareness grows that running a nation is very different to running a business, and this awareness will probably percolate through to New Zealand's foreign policy. What is interesting is to what extent the current cultural diplomacy aims will have long term implications for New Zealand and its foreign policy, which is something discussed in more detail in Chapter 4.

\section{HISTORY}

New Zealand first established a Department of External Affairs in 1943. The aim was to allow New Zealand to build its own relationships with other governments and defend and extend its interests without the previous heavily reliance on the British (Templeton, 1993, p. 23). The ministry's initial focus was on building a professional diplomatic service and dealing with any international issues that involved New Zealand. Cultural diplomacy did not play a big part in its work, and what was there had no special funding and did not use existing opportunities - such as leveraging off the work done by New Zealand artists already established overseas (Marks, 2008, pp 123-4). Mark argues that ad hoc cultural diplomacy and lost opportunities have been a constant of New Zealand cultural diplomacy in the post-war period (Mark, 2008, p. 124).

In the early 1970s, the Cultural Exchange Programme was set up, with the aim of presenting New Zealand's beliefs and attitudes to people overseas (Corner paper to Minister, quoted in Mark, 2008, p. 124). The Programme had two purposes:

"First to cement and to broaden our bilateral relations with countries with which we have important political, economic and defence interests. Secondly, to foster the development and enjoyment of the arts in New Zealand." (Corner memo, in Mark, 2008, p. 124). 
Cultural exchanges were seen as the best way to showcase the New Zealand culture and personality abroad and to help to deepen the cultural experience of New Zealanders at home (Corner paper, in Mark, 2008, p. 124). The rationale was that showcasing New Zealand culture to foreign dignitaries would show how sophisticated its culture was, would raise New Zealand's profile, and could provide opportunities for other New Zealand promotions to leverage off (Mark, 2008, pp 124-125). In time, the focus changed from a two way exchange to an obvious focus on just presenting New Zealand culture abroad (Mark, 2008, p. 125).

During the 1970s and 1980s, cultural attaches were appointed to New Zealand's most significant posts. They undertook cultural diplomacy activities such as maintaining a regular programme of exhibitions and displays; organising official visits to New Zealand; providing books to posts and universities; managing a collection of New Zealand art for showing in overseas missions; and signing cultural agreements (Mark, 2008, pp 125127). The emphasis on cultural diplomacy declined again during the late $1980 \mathrm{~s}$ and 1990s as budget cuts meant that the Ministry of Foreign Affairs refocused its business and moved away from cultural diplomacy (Mark, 2008, p. 145).

In 2004, Helen Clark launched the Cultural Diplomacy International Programme (CDIP). The Programme came out of the importance the new Labour government placed on national identity, with arts and culture at the heart of this identity (Mark, 2008, p. 145). Central to this national identity was New Zealand culture which "speaks to and about our society in a way other activities do not" (MCH, letter to Martin Matthews, 2006).

\section{CURRENT CULTURAL DIPLOMACY}

The Cultural Diplomacy International Programme (CDIP) is a major element in New Zealand's cultural diplomacy. It was set up by Cabinet as an initiative in the context of the then government's economic transformation agenda (MCH, CDIP: Review of Performance after Three Years, p. 10). This gave it a strong economic focus to sit alongside its national identity importance. In New Zealand's case, the international image it has - as a clean, green, friendly nation - is important economically too as much of its tourism advantage rests on this image.

The discussion that follows aims to give a sense of what the combination of cultural diplomacy programmes led by the New Zealand government are seeking to achieve. It 
would be impossible to detail all of the funded activities and initiatives across the whole cultural diplomacy sector in this dissertation, so only a few have been chosen to illustrate the points.

\section{MCH Cultural Diplomacy International Programme (CDIP) programme}

The CDIP helps to establish or maintain a cultural presence in key overseas regions and countries to increase New Zealand's profile and its economic, trade, tourism, diplomatic and cultural interests (DOM Min (10) 41). The programme is led by the Ministry for Culture and Heritage $(\mathrm{MCH})$, with an interagency steering group, made up of representatives from the Ministry for Foreign Affairs and Trade (MFAT), New Zealand Trade and Enterprise (NZTE) and Tourism New Zealand (TNZ) to provide support and advice to the programme. The programme has an annual budget of $\$ 2.090$ million, used to support the presentation of cultural activities.

\section{Objectives and principles}

The objectives and principles of the programme have changed a number of times since its inception.

When the programme first started in 2004, the objectives were to project, in targeted settings, a distinctive profile of New Zealand as a creative and diverse society with a unique, contemporary culture rooted in its diverse heritage; and position New Zealand among targeted overseas senior government and business leaders, representatives of the creative economy, and thereby the wider population, as a country they understand and want to engage with (DOM Min (10) 41). In 2010, the objectives changed to what they currently are (CDIP at a Glance Factsheet): to contribute to growing New Zealand's economic prosperity by presenting our culture to key audiences; and to project in targeted settings, a distinctive profile of New Zealand as a creative and diverse society with a unique, contemporary culture.

The principles of the programme have also changed over time, although not as obviously. The earlier principles were weighted towards adding value to New Zealand's trade, tourism and diplomacy and promoting New Zealand's interests overseas. It was important that there would be no duplication of work by other agencies and programme messages will not be inconsistent with the national brand position of clean, green, 
innovative, creative and technologically-advanced. The principles did, however, emphasise a strategic approach and promoting broader interests.

In June 2010, these principles changed to be about funding initiatives that will link to economic outcomes for New Zealand; showcase cultural activity that is distinctive and contemporary; and demonstrate collaboration between the four core agencies (CDIP at a Glance Factsheet). The new principles make the economic focus of CDIP very clear with an emphasis on economic outcomes and using innovative and modern activities to showcase New Zealand. Trade and tourism objectives are heavily represented through the input of the core agencies. While the brand is not specifically mentioned in the new principles, it is clear that the cultural diplomacy programme has a close alignment with the national brand.

The CDIP focus has gradually changed from what was a clear cultural diplomacy imperative in 2004 and has been refocused as a programme delivering culture for economic ends. True argues (True, 2006, p. 73) that New Zealand governments have seen globalisation and global integration as a way for New Zealand to improve its economic position and to "expand its international influence in global governance and multilateral forums". The current government appears to place less emphasis on culture and influence in multilateral forums, hence the more prominent position of economic aims in the objectives. This view can also be seen clearly in the activities selected and the geographical areas identified as priority areas (discussed further below).

\section{Selecting activities}

In its early days, the programme delivered cultural activities overseas that were strategic and focussed on priority countries or regions, using a multi-year, sustained approach; targeted at key sectors of the population or key events in the region; planned well in advance, possibly with two to three years lead time; and suited to advancing New Zealand's diplomatic and trade interests (MCH website).

To be selected now, cultural activities must be excellent and distinctive, able to project the contemporary face of New Zealand (that is, unique, creative, innovative, moving ahead). The activities have to be of sufficient scale to use significant venues, have maximum impact and media profile. They will be layered in such a way as to build a cultural presence; and suited to cultural diplomacy purposes and promoting New Zealand Inc interests in the particular country or region. Finally, they must be able to engage the 
target audience (government, business and opinion leaders and through them, the general public).

The earlier selection criteria are much more old fashioned diplomacy with their emphasis on an approach that is well planned and strategic, targeting a key audience and advancing diplomatic and trade interests. The current criteria share more in common with marketing principles: the events need to be big, distinctive and able to build and maintain an impact and they need to appeal to a much larger audience than just the state's elite. The events also need to be suited to cultural diplomacy purposes - but in the same line, they need to promote New Zealand (NZ) Inc interests. NZ Inc is an approach which uses the collaboration of the 4 core government agencies, and lets their achievements be leveraged off through sponsorship from others, including New Zealand firms represented in the target country, or local firms with New Zealand interests. It has a strong trade and economic focus. Combining it and cultural diplomacy in the same criterion, giving one an active verb and one a more passive verb, tends to suggest cultural diplomacy interests may be subordinate to trade interests - or at least, be seen as one and the same thing. The economic agenda is easily seen here too, but there is also a move towards the acceptance that, as True says, "image and reputation are an essential part of the nationstate's competitive advantage in the global political economy" (True, 2006, p. 74).

\section{Geographic focus}

The current seven year focus of the CDIP programme is Asia, especially China, Japan and Korea, and in June 2010, Cabinet agreed that the future focus of the CDIP was to continue to prioritise proposals for the Asia-Pacific region (MCH, BR 2010/229). The rationale for this was that CDIP was seen as a "useful tool to maintain and develop a network of strong relationships to achieve the Government's diplomatic and economic priorities" in the Asian region (DOM Min (10) 41).

The Cabinet paper also recommended that CDIP include some targeted initiatives in the United States (MCH, BR 2010/229), which fits with the MFAT goal of strengthening relationships with New Zealand's bilateral partners - Australia, the United States and Europe (MFAT SoI p. 5; Annual Report, p. 18).

The CDIP does do some activities in non-Asian countries, but the majority of its work is targeted at the Asian region. Asia is seen as a region that is closely aligned with the NZ Inc objectives and strategic directions, which are predominately economic $(\mathrm{MCH}$, draft, 
“Selecting CDIP's Priority Region and Cultural Activities"). In 2006, a draft paper identified Asia as "a region where cultural diplomacy is part of doing business. It is an understood way of cultivating ties, fostering understanding and long-term relationships and building a platform of business interests" (MCH, BR 2006/532). This view of cultural diplomacy is very business and economic focussed and reflects a differing view of cultural diplomacy, where business is the culture that eases other diplomatic wheels.

This is not to say that culture has not made an appearance in the cultural diplomacy programme. The New Zealand presence at Expo 2010 in Shanghai used Maori and Pacific cultural performances and showcased New Zealand products. However, as in almost all areas of the CDIP relationship with China that were examined, the result of this cultural presence was to be "to add significant value to NZ Inc efforts in China in the context of implementation of the recent FTA and the need to raise New Zealand's profile throughout China in order to maximise the potential benefits" (MCH. BR 2008/286). Culture as a way to impart a story is no longer enough - increasingly programmes approved need to demonstrate they have an associated economic benefit.

There have been examples of cultural diplomacy that are undertaken for reasons other than the economic spin-offs, but these are becoming increasingly rare. One example is the recent NZSO tour to Europe, which is discussed further below. Since its beginnings, CDIP has used the NZSO to promote New Zealand's cultural profile. This is purely a cultural exercise: there is little or no benefit to New Zealand economically in being seen to have a world class orchestra. In 2004, funding for the NZSO was justified on the grounds that "cultural activities can be used in a structured way to present a rich and diverse image of New Zealand and engage the interest of overseas governments and business leaders in New Zealand as a country they understand and wish to do business with" (POL (04) 119). While economics are not absent from this rationale, there is an understanding that culture can provide other benefits too.

\section{Other creative programmes}

Cultural diplomacy is also carried out in the government space by other arts, culture and heritage crown agencies, three of which are Creative New Zealand, The Museum of New Zealand Te Papa Tongarewa (Te Papa) and the New Zealand Film Commission.

Creative New Zealand's statutory purpose is to encourage, promote and support the arts in New Zealand. The Creative New Zealand International Strategy aims to support the 
development and presentation of distinctive, high quality, 'international-ready' art; develop international markets and audiences for New Zealand art; and build the skills and capability of the arts sector for engaging internationally (CNZ International Strategy, p. 2).

Clearly this strategy is not cultural diplomacy in a usual sense as it lacks any real sense of seeking to promote mutual understanding. The emphasis is on the benefits that can accrue to the New Zealand artist and any increased understanding with overseas colleagues is a bonus. It is primarily an economic role, with benefits for New Zealand artists. The value of this strategy is that not only does it gain advantages for individual artists but, in doing so, it adds to the material that constitutes a unique New Zealand culture.

The roles played by Te Papa and the New Zealand Film Commission have more of a showcase and dialogue role. The New Zealand Film Commission provides support for the development of New Zealand cinema. It works actively to promote New Zealand films overseas and provide links for film makers with the international market (CNZ, SoI p. 10), bringing New Zealand's stories and images to the world.

Te Papa's purpose is to present, explore and preserve the nation's heritage. It shares New Zealand's heritage by organising overseas exhibitions to give foreign audiences an introduction, or gateway, to New Zealand's natural and cultural heritage (Te Papa, SoI p. 17). In this way, Te Papa builds relationships with other museums in the world, and also contributes to the presentation of New Zealand's national identity overseas.

\section{Sports diplomacy}

Sport has long been accepted as a valuable soft power tool, with sports teams acting as symbols of their nations. Sport is a strong part of national identity and successful teams can attract money and events to nations, providing an economic advantage (Xifra, 2009, p. 504). A country such as New Zealand, which is small but which has had notable sporting successes, can use its sports teams to promote its interests. Not only in branding, but also in cultural diplomacy, sports teams can show the values of the nation and provide a way for other countries to engage.

In June 2010, agreement was sought from Cabinet to amend the CDIP programme so that funds could be used for on-shore activities to support the Rugby World Cup Festival 
(NZ2011 Festival) (DOM (10) 41). The rationale for this was that the aims of the programme - supporting initiatives offshore that boost New Zealand's profile and economic, trade, tourism, diplomatic and cultural interests - could be met by "capitalising on the large numbers of influential visitors and world attention in New Zealand" (DOM (10) 41). This action has shown the importance sporting events have for New Zealand, both economically and as a forum for promoting our unique culture. It is not an isolated event in New Zealand's history: the America's Cup saw New Zealand capitalise on its sporting identity to attract investment and showcase itself (True, 2006, p. 78).

Cultural diplomacy and the economic advantages of sport can also be seen with the All Blacks. In 2007, IVECO, an Italian commercial vehicle manufacturer, became a global sponsor for the All Blacks because they saw them as an iconic brand whose team values were consistent with IVECO's core values (performance, commitment, reliability, and team spirit) (MFAT cable, 2007). MFAT worked with IVECO to leverage off this sponsorship and use the foreign investment to promote New Zealand's own interests and image. A number of activities to promote New Zealand were undertaken in Italy, and MFAT took advantage of the All Blacks' and IVECO's presence in France during the 2007 Rugby World Cup to promote New Zealand further (MFAT cable, 2007).

Using the All Blacks as ambassadors and symbols of the national identity allows New Zealand to promote its culture and build relationships with other nations. The nation supports its teams, their enthusiasm, energy and skills attract tourism and foreign capital, and the obvious success of the teams keeps New Zealanders supporting them and pumping money into them (True, 2006, p. 80). Sport as diplomacy very easily straddles the culture and economics divide.

\section{ELEMENTS AND EXAMPLES}

In this section, the elements considered to be important to cultural diplomacy are examined in more depth: the role it plays in promoting understanding between states; its use of national identity to create a stronger cultural sovereignty; advancing the national interests of the state overseas; and the way in which it complements more traditional diplomacy and foreign relations. Examples of New Zealand's cultural diplomacy programmes are shown to see where these elements are demonstrated. 


\section{Promote understanding in foreign countries}

Governments exchange ideas and culture to promote mutual understandings with other countries and combat stereotypes. There is often some advantage to a country in doing this: if understanding of it is expanded in a target state, that state may want to engage more, support objectives or buy products.

In August - December 2006, the CDIP contributed money to a co-production producing five one-hour documentaries about New Zealand, to be screened on Chinese television. The idea was to promote New Zealand as a sophisticated, innovative state, then leverage off the televisions shows - estimated to reach an audience of 11 million on Chinese televisions and 90 million on Asia Discovery (in the event, it was estimated over 300 million viewers have seen the New Zealand documentaries) (MCH, CDIP: Review of Performance after Three Years) - and use the interest the shows garnered to promote additional cultural diplomacy in China.

At the same time as the television shows were planned, Te Papa Tongarewa had planned a touring exhibition, aimed at presenting contemporary New Zealand to Chinese audiences. New Zealand was shown as "diverse, vibrant, distinctive and innovative" and its objective was to develop New Zealand's image to potential consumers of New Zealand's products and services.

To go alongside these two planned events, a NZ Inc approach was planned to include private sector involvement in promoting New Zealand's tourism, trade, education and business interests in China.

The initiative was a success in that a large number of Chinese saw and experienced images of New Zealand and were given the opportunity to back up their new knowledge with easy access to New Zealand products.

\section{Expression of national identity}

Cultural diplomacy can help present a national image abroad and this in turn allows the domestic population to examine what their identity is.

Te Maori was an exhibition of Maori artwork that toured the United States in 1984. Its aims were to increase the mana of the Maori people; give Americans a further awareness 
of New Zealand; and provide an opportunity for New Zealand to further other interests in the US (Mark, 2008, pp 129-130). Its success both overseas and when it returned home in 1986 contributed to the Maori cultural renaissance (Royal, Te Ara website) and created a huge amount of international recognition for New Zealand (Mark, 2008, p. 131).

Mark describes Te Maori as "arguably New Zealand's most successful cultural diplomacy event" (Mark, 2008, p. 122). The foreign affairs ministry used the exhibition to organise associated activities to fit with the exhibition and help advance New Zealand's trade and tourism interests (Mark, 2008, p. 128) and it achieved the two aims of the Cultural Exchange Programme, described above: it gained international recognition for New Zealand's culture, and it had a strong domestic impact.

It also had a very strong impact on New Zealand's identity: Maori found themselves and their culture visible on a world stage (Art New Zealand, website) and Pakeha New Zealanders who had not had a wide exposure to Maori culture suddenly found themselves able to engage with it. Barbara Goodman, writing about the Te Maori dawn ceremony for Metro said "on that night, for the first time in my life, I was able, invited even, to join it. An amazing thing happened. After all these years I, who had been born in New Zealand, knew I was utterly, completely a New Zealander" (quoted in NZ history, website).

\section{Pursuing domestic objectives}

Cultural diplomacy programmes often work towards advancing the domestic interests of the state. In New Zealand's case, this is made explicit in the objectives of CDIP, where the first objective is to contribute to New Zealand's economic prosperity.

Often, culture is the way in which a country can get a foothold in another state and get itself noticed. By using this foothold, a state can pursue domestic objectives and gain some advantage for its national population. One obvious example, mentioned above, is the 2011 Rugby World Cup. The money agreed to by Cabinet in 2010 (DOM Min (10) 41) will be used to support the 2011 Rugby World Cup and the associated NZ2011 Festival. The events and the games will bring money into New Zealand and will also advance the interests of groups chosen to showcase their talents at the festival, such as Te Matatini: the national kapa haka association. 
Domestic objectives have also been pursued in the area of science, where Korea and New Zealand have been working together to grow the potential of elderly care robot technology. A joint research centre was opened at the University of Auckland in 2008 to look how to develop and commercialise the technology. Robots are being tested in New Zealand, prior to being sold on the western market. This collaboration is expected to create new, high value export markets for New Zealand.

\section{Protection of cultural sovereignty}

One of the roles of cultural diplomacy is to protect the cultural sovereignty of a nation. If the culture of a nation defines it and its identity to the world, it is important that the culture being portrayed is as good as it can be and has some appeal for an outside audience. A strong culture, as Marks points out (Mark, 2010, p. 71), generates jobs for the practitioners of the culture and protects them against foreign competition, and builds a strong identity for the nation.

In 2010, the New Zealand Symphony Orchestra went on a three week tour of five countries: China, Germany, Switzerland, Slovenia and Austria. This trip was not seen to be one that would present any economic advantages for New Zealand and nor would it give any opportunities for other thing to be leveraged off (MFAT email, 2010). Instead, the visit was viewed as an expression of New Zealand's cultural capabilities and a chance to showcase New Zealand's national orchestra.

The tour is considered to be one of the NZSO's most successful in its history and has been described by Arts, Culture and Heritage Minister Chris Finlayson as being hugely important for New Zealand's reputation (The National Business Review, 2010).

The successful tour has generated pride in New Zealand for its national orchestra. Having a reputation like this gives benefits to the orchestra, who can use their international success to lobby for more government money, gain more private sponsorship and market their reputation to attract talented players. A reputation for

being world class may also translate into a bigger profile in New Zealand and the gaining of a larger audience. Such public acceptance can also translate into more funding for the orchestra and a greater sense of pride for all New Zealanders in their identity. 


\section{Complements traditional diplomacy}

Culture is often used to serve traditional diplomacy by finding common, non threatening ground with other countries and building relationships. In the past educational exchanges were often used to do this.

The Cultural Diplomacy and International Programme was set up to establish a New Zealand cultural presence overseas so as to boost New Zealand's "diplomatic, trade, economic, tourism and cultural interests" and had as its primary audience senior government and business leaders (CDIP: Review of Performance after Three Years). With this aim, almost all its early events could be seen to complement traditional diplomacy, but three examples highlight how culture can help in a wider diplomatic sense.

In 2006, New Zealand gifted two paintings to the new Quai Branly Museum in Paris. The goodwill generated by the gift proved to be of value later to New Zealand when the Quai Branly curator offered to act as a go-between between the government and the owner when New Zealand was attempting to have a Maori taonga, illegally exported in the 1970 s, returned.

In October 2005, the people and government of New Zealand gave a white horse (Kotuku) to the Japanese shrine of Toshogu. The gift symbolises the importance of the Japan-New Zealand relationship and in 2007, the Chief Priest of the Shrine and a delegation of 100 visited New Zealand to say thank you for the horse. The gift gained very positive media coverage in Japan and has contributed to the good relationship shared by Japan and New Zealand.

In 2008, the CDIP contributed funding towards the development of an urban park in the heart of Santiago, incorporating New Zealand flora, imagery and materials. The plaza was a gift from the government of New Zealand to the people of Chile in their Bicentennial year. The New Zealand Ambassador inaugurated the Plaza in November 2009 , saying the urban space was "a permanent reminder of the friendship between our two countries" (Plaza Nueva Zelandia proposal, 2009). 


\section{CONCLUSION}

Cultural diplomacy is the way in which a state uses its unique culture to form relationships, and the way other states and maintain and build these relationships over time. As discussed above, New Zealand has a range of ways in which it uses its cultural resources to interact with other countries, ranging from collaborative, whole-ofgovernment initiatives to single agency approaches.

The changing world we live in has meant that the nature of diplomacy is also changing. Government to government interaction is no longer the only form of interaction: other organisations, including non government agencies and private individuals, now interact in the diplomatic space and their promotion of the things that interest them affect how countries are seen.

Cultural diplomacy is an important part of a state's foreign policy. As shown above, New Zealand's cultural diplomacy, while primarily concentrated in the Cultural Diplomacy and International Programme, is also contributed to by programmes run by individual cultural agencies and iconic sports teams with international profiles and pulling power. Other government agencies, not mentioned above, such as science and education, also contribute as they have clearly defined peer groups in other countries with whom they have strong and productive relationships. All these forms of culture serve to showcase New Zealand's achievements overseas and add to its soft power.

New Zealand meets the cultural diplomacy components identified at the start of the chapter: it does showcase its national identity in different arenas, and promotes understanding of the nation in other countries. Its cultural sovereignty is protected and it pursues domestic objectives and uses culture to complement traditional diplomacy.

In general, however, New Zealand's cultural diplomacy has been gradually moving from a long term investment in relationships, using culture as the mutual meeting ground, to a more economically focussed approach which uses culture as just one more tool in a marketing strategy aimed at gaining a trade advantage. To be fair, there are a range of instances where presenting New Zealand's culture is done purely for the sake of sharing, but the general trend is either towards finding an economic use for culture, or in using it to pretty up what is a trade initiative. This does not mean that the culture being presented is not well received, or intended as a gift of sorts, and nor does it mean that the relationships being built are necessarily short term or bad. The relationships being built 
are different, however - they are more explicit about the benefits expected by both countries, and less concerned with finding mutual ground. The presentation of culture is less about sharing a gift, and is more about what benefits each side can get. This has already begun to change the nature of diplomatic relationships and may have wide ranging implications in later years. 


\section{CHAPTER THREE \\ THE ASSET OF EMOTIONAL CAPITAL: CREATING AN \\ IMAGE OF NEW ZEALAND}

The definition of nation branding used in this thesis is that it is the way in which a state creates a distinctive image of itself in the minds of an audience and then actively markets this image, or brand, to create a sense of value in the mind of the consumer. By differentiating itself in the international market, a state can create markets and attract customers.

To differentiate itself, a nation needs to find things that set it apart from other countries. Countries frequently draw on the national identity to create a shorter, snappier brand to sell overseas. For New Zealand, the main points of difference have been its landscape, its culture (particularly the Maori and Polynesian aspects) and its sport - all strong parts of the New Zealand identity.

Once the brand has been decided on, a nation needs to start finding assets that it can use to build and manage the image it has created. New Zealand has some advantages and disadvantages in this area: its isolation means it has a strong exotic element and its history has given it some clear messages, such as clean and green, or nuclear free, that give it an advantage in today's world. New Zealand also has a large ex-pat community which it can call on, and it has some very strong, internationally known images, such as the Lord of the Rings films and the All Blacks. It is disadvantaged by being far away from the rest of the world, and it is small and lacks the money to promote itself hard. New Zealand really does need to be more innovative than other countries in getting its message across.

When the brand has been established, a market needs to be created. This must be an ongoing process as brands and products can grow stale and need to be renewed and revitalised.

Below, the thesis looks at the New Zealand brand to see what elements went into its creation, how it has been maintained and managed, and how Tourism New Zealand is looking at developing or growing it. The relationship between a nation's identity and its 
brand to see how the two might work together is examined, and how the elements of the national identity work to create reputational capital for the nation.

\section{THE NEW ZEALAND BRAND}

The New Zealand brand started out, and remains, primarily a tourist brand. New Zealand has recognised the economic potential of tourism since the nineteenth century when it began using the landscape and culture to attract tourists (Ateljevic, 2002, p. 653), and in 1901, the government opened the first tourism board in the world (Morgan, 2002, p. 342). The current Tourism New Zealand was established as a Crown Entity in 1991. Its aim was to improve tourism's contribution to New Zealand's overall economy by monitoring and continuing to strengthen the strong New Zealand brand overseas (TNZ Annual Report, p. 1).

New Zealand is one of the few countries in the world that funds a large part of its tourism from public money (TNZ baseline summary, p. 30). This decision was made in the 1990s, when it became clear that marketing initiatives were scattered, with no one consistent brand (TNZ baseline summary, p. 30). In 1999/2000, the Tourism Strategy Group was formed to develop a strategy for the New Zealand tourism industry. Its overarching aim was to "provide a framework for decision making that will allow the tourism industry in partnership with government to face the future with confidence and build the capabilities for sustainable growth" (TNZ baseline summary, p. 8). The initiative has been extremely successful, with New Zealand now having a very strong, well regarded brand. In conjunction with this initiative, agencies working internationally have the NZ Inc approach (discussed in the preceding chapter) which allows the four core government agencies to leverage off events in the cultural diplomacy / branding space.

A tourism brand works because it uses emotion to appeal to an audience: early images of New Zealand were heavily oriented to the English upper classes, reflecting the values of their class (Ateljevic, 2002, p. 655). Today, by choosing to come to a far away country famed for its space, isolation and adventure, tourists are still displaying aspects of their own personalities (Ateljevic, 2002, pp 662-663). These attributes are projected onto the New Zealand landscape, imbuing it with attributes that the consumer values.

A brand uses imagery that reflects a certain set of values, including those of the host nation and those that will appeal to the target nation. New Zealand's international image rests on the $100 \%$ Pure New Zealand brand. It was launched in July 1999, with the aim 
of communicating a strong, consistent message that provides people with an enduring image of New Zealand and convinces them the country is worth visiting (TNZ, 100\% Pure NZ handout). The representation in the $100 \%$ Pure NZ advertisements is of a nation of great natural beauty, allowing for a number of outdoors and adventure sports. The country is also young, thus innovative and full of products that both use the natural wealth of the country and show the inventive and novel approaches New Zealanders take.

In the first six years after its launch, tourism became New Zealand's biggest earner, visitor numbers doubled from 1.6 million to 2.4 million, and foreign exchange earnings went from \$NZ3.5 billion to \$NZ5.9 billion (TNZ 100\% Pure New Zealand: Website $100 \%$ Pure NZ facts and figures). In the 2009 Country Brand Index, it was ranked as the fourth most successful country in marketing itself and its brand internationally (Country Brand Index, 2009, p. 4).

\section{NATIONAL IDENTITY}

National identity is important to nation branding as the essence of a nation's brand has to come from the country's culture (Dinnie, 2008, p. 111) True says a state must nurture the cultural assets and national identity of the nation to attract international investment and talent (True, 2006, pp 80-81). Anholt says that "the image of a country determines the way the world sees it and treats it" (Anholt, 2005, p. 105), while for Dinnie, nation brands that are based on national identity have a richer, deeper cultural resource and are stronger and more resilient (Dinnie, 2008, p. 14). Skinner and Kubacki say the nation brand matters because it is linked to national identity, which is then linked to cultural and political identity (Skinner, 2007, p. 307), and Fan says branding your nation is all about exploiting your soft power resources to effectively promote a national image (Fan, 2008, pp 147-155). A nation brand is a nation's identity, and a nation's identity is the sum total of its people - making the brand a very personal thing to the nation's population.

All nations are seen by outsiders as being associated with particular qualities and values, and people hold a set of stereotypes in their heads about other countries. These perceptions have a big impact on how overseas consumers will view a nation and treat it, from buying its products to its attitude to their sports teams, politics and culture (Anholt, 2005, p. 105). To change their minds, states must actively market their country. One of the best ways to do this is to have the population of your own country believing in the image of the nation so when it is sold overseas, the domestic population not only believes 
the image, but actively lives and models it (Anholt, 2005, p. 119). If the brand reflects the national identity, people will instinctively live it.

Basing a brand on national identity is difficult, however, because national identity is an abstract concept. Populations are too big, fragmented and different to ever agree on all things - Benedict Anderson argues that nations are invisible: they cannot be seen in their entirety and must be imagined by their nationals. The nation is limited because it is not global, a community because it has a sense of comradeship that unifies the nation, and imagined because only a percentage of the community will ever know the whole community (Anderson, 1993, p. 15).

Despite this, governments work hard to produce a sense of identity and how a country chooses to market itself is a powerful indicator of how it sees its people and culture. In a country with a number of diverse and different people, the things that link people together must be neutral yet familiar enough to provide a sense of companionship without any tension. Landscape and culture are two areas that can give all the occupants of a nation this sense of kinship. Landscape, in particular, has been vital to the New Zealand brand and this is discussed, along with the role culture plays, below.

\section{Geography/Landscape}

One definition of a nation is "a named human population sharing an historic territory, common myths and historical memories, a mass, public culture, a common economy and common legal rights and duties for all members" (Smith, 1993, p. 14). Smith says that the Western or civic model of the nation is a "predominantly spatial or territorial conception" - people and territory belong to each other (Smith, 1993, p. 9). The land is a place where history and associations cluster around the natural features, making them sacred. Territory is also one of the five dimensions Guibernau sees as important for national identity. For centuries, an individual was defined by the territory where he/she lived (Guibernau, 2007, p. 21), meaning the physical landscape has always been central to the human condition in defining how we see ourselves and how we live our lives.

Landscape works because it is immediate, obvious and visually impressive. It gains more power because it is a powerful visual manifestation of national identity (Dinnie, 2008 , p. 114). Because it has such significance for the native population, it also has great power for tourism because the country's inhabitants can communicate their views of the landscape in a way that resonates with the target audience. 
The challenge for brand marketers is how to make the landscape mean more than just tourist imagery. How the $100 \%$ Pure New Zealand brand has managed to do this is discussed below.

\section{Culture and sport}

Culture is important in selling a nation brand because, as Anholt says, "in the face of the consumer's suspicion of commercial messages, culture is self-evidentially 'not for sale'." (Anholt, 2005, p. 136). Culture, like a country's landscape, is a unique feature (Anholt 2005 , p. 136) and it also belongs to the whole nation, even if certain aspects or groups are valued or given more importance than others.

Culture is also a shorthand for values: sporting nations are seen as resilient and strong; countries with strong youth music and art are innovative, young and fun; fashion industries give you flair, creativity and sophistication (Anholt, 2005, p. 137). Consumers can use this shorthand to give them a wider sense of the nation and its associated products.

Culture is also vital for the regeneration of products, making sure they stay fresh, relevant and desirable. Without culture, without creative people and innovative and new ways of doing things, a nation's products will not grow and constantly appeal to the market (Anholt, 2005, p. 140). Governments need to be aware of this and make sure that domestically, culture and cultural agents are financed to keep producing the products that the brand depends on.

Culture is how the brand is raised from being more than just a marketing exercise to the showcasing of culture (Anholt, 2005. p. 140). Culture allows your transactions to be more than monetary and become something more about dialogue, creative discussion and sophistication.

\section{What is the New Zealand identity?}

Articulating a New Zealand identity is always difficult. Identities are fluid and no one definition is ever going to reflect all the people who live under that identity. Due to constraints, this section can only ever be a very light view of the New Zealand identity, and cannot go into any sort of depth or analysis about the national character. 
In general, New Zealand can be seen as the story of many different groups of people:

Maori, whose identity has been shaped by an alienation from their land and culture and a struggle to maintain their culture as a minority group; Pakeha New Zealanders whose identity is that of immigrant people reacting with a new land and becoming part of it; and newer non-Maori immigrants who are adjusting to New Zealand while still dealing with the ties of another country. For all New Zealanders, old and new, their identity as New Zealanders is tied to the sense of connectedness they feel to the country and the sense of belonging they have in New Zealand society.

The last government had national identity as one of its goals, and defined it as :

"our lifestyle, our environment, our historical heritage, our creative people ... make [New Zealand] unique. Through the arts and through cultural activities we New Zealanders express our aspirations as a nation, who we are, and where we stand in the world." (1999 Labour Party Cultural manifesto - quoted in MCH, BR $2009728)$.

For the Labour government, a nation that proudly and confidently asserted its identity through its culture and heritage was a nation that could hold its own in the world (Helen Clark, 2000). For this reason, the government was committed to promoting arts, culture and heritage to help New Zealand brand itself internationally. The new National government, elected in 2008, had different priorities, recognising that arts, culture and heritage were important in enriching the lives of New Zealanders, but seeing a more hands off role for government (National Party, Arts, Culture and Heritage Policy, 2008). High priority areas were those that would aid New Zealand's economic growth and not intangible areas such as national identity.

In a 2008 discussion paper, prepared for the Ministry for Culture and Heritage, James Belich and Lydia Wevers discussed New Zealand's cultural identity and found some areas they considered to be central to the New Zealand identity: a classless society; the attachment to the rural landscape; the dark or puritan "kiwi gothic" aspect that underlies the surface; a masculine focus; and a strong sense of humour (Belich, 2008, pp 4-8).

In a 2010 Listener article, Jane Clifton looked at what it means to be a New Zealander (Clifton, 2010, p. 14). The top attribute was that New Zealanders have a deep relationship with the land: "New Zealanders' sense of self-definition is heavily bound up with love of the natural world". Independence and a high value put on freedom was also 
important, as was masculinity of expression - or, a culture that expects citizens to show gumption, and demonstrate capability with physical tasks. Sport is very important, as is valuing friendship and "mateship". Finally, New Zealanders are easy-going and modest and have an understated, laconic humour, often used to defuse conflict.

None of these characteristics are surprising. New Zealanders have always had a deep attachment to their landscape and the independent, easy-going, quietly capable and modest New Zealander who loves sport and values his/her mates has long been the stereotype of a New Zealander. It is perhaps a more Pakeha male centred view, but most elements can be applied equally to men and women, and Maori and Polynesian influences are seen in many of these characteristics, especially the relationship with the land, sport, the humour and friendship.

The challenge is how such a group of values can be turned into a brand that the population sees, responds to and internalises as being really them. In the case of the $100 \%$ Pure NZ brand, it drew on landscape initially to identify the nation. New Zealand's landscape has always been a drawcard for tourists (Ateljevic, 2002, p. 653), but the brand managed to turn it from a passive backdrop into a more active character in its own right. It is marketed as an adventure landscape - meaning you have to interact with it to get the full enjoyment out of it.

Related to this is the way in which New Zealand's innovative and cultural activities develop from the landscape. The two predominant New Zealand cultures, Maori and Pakeha, both rely heavily on the land to form part of their identities and tell their stories and histories. The landscape sits behind everything New Zealanders do and it is a central part of the way they view the world. The brand has used this, utilising the Maori myths of Rotorua or the history of the Otago goldfields to sell the brand.

The landscape imagery was extended (a process ongoing today) to incorporate aspects of New Zealand life that New Zealanders can identify with. The Youngest Country campaign drew on New Zealanders' unease with being a new country and lacking the gravitas of older nations, making it ok to be young - in fact, tying the youth of the nation's modern history into being vibrant, innovative and alive and thus a positive thing.

Since January 2011, the brand has repositioned itself away from the landscape and has begun to focus on what you can do in New Zealand, and how it will make you feel (TNZ website). This takes the already established landscape and culture imagery but shifts it. 
The values of New Zealand are already well established - now the challenge is what can be done by visitors in this landscape. It is a move away from the domestic market and seems targeted solely at the international market. This is because the $100 \%$ Pure NZ campaign has been so successful that New Zealanders have already internalised the brand and future campaigns do not need to work to engage them.

\section{CREATING REPUTATIONAL CAPITAL}

Once a nation has decided on the essence of its brand and what images will be used, the brand needs to be put into the market and a good reputation created for it.

To get a brand to appeal to a market, the core values must be established and then it needs to be positioned and advertised successfully (Morgan, 2002, pp 344-352). The brand needs to generate an emotional response from the consumer (Morgan, 2002, pp 340-342).

As discussed above, nation branding is successful when the brand is lived by the citizens (Anholt, 2003, p. 123). A citizenry who live the message do much to help create a positive and cohesive reputation overseas, thus gaining benefits for the nation which is branded consistently and believably in the international market (Szondi, 2005 p. 5). Governments also play a role by helping create a national identity that everyone shares in and which has a resonance for people overseas, and creating an environment where industry can grow and produce products that are valued offshore (Gudjonsson, 2005, p. 285).

\section{Establishing the brand}

The core values of the nation will make up the brand, but these values have to be tailored to suit the target market (Morgan, 2002, p. 344) so that the brand can begin to create a response in the consumers.

Prior to the $100 \%$ Pure NZ campaign, New Zealand's tourism budget was very small and fragmented. There were a number of initiatives by different markets but the money vanished into the international market without making much of an impact. New Zealand, a small, far away country, with a negligible budget, could not compete with larger countries with tourism offices around the world (TNZ. Pure As; Celebrating 10 Years of $100 \%$ Pure New Zealand, pp 8-10). It was decided that what New Zealand needed to do 
was brand itself consistently, selling the "true essence of this country" (TNZ. Pure As; Celebrating 10 Years of $100 \%$ Pure New Zealand, p. 10). In this, it would copy successful brands such as McDonalds and Nike, the images and brand instantly allowing people to know what they were looking at.

The first step was the tagline $-100 \%$ Pure New Zealand. It, along with the map of New Zealand replacing the line in the percentage sign, was easily understood by people around the world; instantly recognisable, and it "reflected what New Zealand is about". (TNZ. Pure As; Celebrating 10 Years of 100\% Pure New Zealand, p. 12). The tagline was the core around which the rest of the brand was structured - other layers could be added, but the tagline had to remain consistent.

The tagline, teamed with the imagery of a scenic and adventurous land, established the brand as a player in the international market. Once established, it had to be positioned to attract more visitors.

\section{Positioning the brand}

The 100\% Pure NZ brand, alongside the Lord of the Rings and Narnia films, gives New Zealand a strong brand that ties the name to images of overwhelming landscapes and unspoiled beauty (Donaldson, 2006) - the central message of the brand is that New Zealand has a "stunning natural environment" (Morgan, 2002, p. 343).

The landscape is stunning, but is also invested with values: untainted, unadulterated, unaffected and undiluted (Morgan, 2002, p. 348). The landscape and what it symbolises brings visitors to the country, and the positioning of New Zealand as an adventurous new land and culture on the edge of the Pacific is firmly rooted in the landscape (Morgan, 2002, p. 346). The values that underpin the "new Pacific freedom" - contemporary, sophisticated, innovative, creative, spirited and free - rely for their power on being part of a beautiful and adventurous landscape (Morgan, 2002, pp 347-8).

The core values were developed after much market research overseas showed that foreign visitors perceived New Zealand as being scenic, safe, clean and pure, with a distinctive cultural heritage and culture, good food and accommodation and plenty of adventure activities (TNZ baseline summary, p. 18). In developing the brand, the research team determined that New Zealand had four major assets: landscape, people, adventure and culture (Morgan, 2002, p. 346). 
There was a difference in how different countries viewed New Zealand: the French and Germans were more positive and had more understanding of the landscape, produce and Maori culture; whereas the British had a very old-fashioned view of a sleepy, bungalowridden suburbia (Dinnie, 2008, p. 28). The existing images of New Zealand of green pastures and sheep bored people - and these images were not what people saw when they came here. Overseas visitors said they found New Zealand's landscapes exhilarating and exciting (TNZ. Pure As; Celebrating 10 Years of 100\% Pure New Zealand, p. 12).

In order that the message was not diluted, TNZ chose to concentrate on the real travel and special interest segments of the UK and European markets, creating a brand that was all about a new and untouched landscape (Morgan, 2002, p. 347). At the launch, the imagery was of "pristine alpine scenery, dramatic landscapes and sweeping vistas nature in its purity" (Tourism New Zealand website, 2010). Only after this image had been fixed in people's minds did the campaign widen to allow other images of a more urban and sophisticated New Zealand (Tourism New Zealand website, 2010).

The initial campaign did well, creating interest overseas. Within a year, New Zealand was considered a "hip destination" and was the top long-haul destination for many British (TNZ. Pure As; Celebrating 10 Years of 100\% Pure New Zealand, pp 15-16).

There are several reasons why the campaign did well. Firstly, it perfectly summed up the New Zealand environment, seen by overseas visitors as a calm oasis away from the chaos and mayhem of their daily lives (TNZ. Pure As; Celebrating 10 Years of 100\% Pure New Zealand, p. 22). Secondly, it has been a consistent message, combining many elements but remaining true to the core message (Morgan, 2002 p. 345). Thirdly, the brand resonated just as strongly with New Zealanders as it did with people overseas (Dinnie, 2008 , p. 28). Finally, the nation-branding project was initiated and driven by people with an acknowledged vested interest who had the will, authority and budget to make it work (Dinnie, 2008, p. 28).

Since then, New Zealand has extended the brand and the current top five brand strengths of the New Zealand brand are: spectacular landscape and scenery; getting in touch with nature; clean and unpolluted environment; commitment to sustainable environmental management; and a safe and secure destination (TNZ website: Update, October 2010). 


\section{Marketing the brand}

The campaign combines advertising, media work overseas, events and working with trade ventures around the world to promote New Zealand. Tourism New Zealand look at ways of leveraging off other New Zealand campaigns - for each international event, TNZ tries to attract media coverage and promote New Zealand as a destination (TNZ. Pure As; Celebrating 10 Years of 100\% Pure New Zealand, p. 29).

As examples, the America's Cup was used to promote New Zealand scenery and, when Team New Zealand was invited to display the Cup at Cowes, it was decided to return it in a dingy, with a dawn ceremony and a conch shell announcing its arrival. This generated a lot of media coverage and succeed in showing New Zealand as an "open society, unfettered by club rules" (TNZ. Pure As; Celebrating 10 Years of 100\% Pure New Zealand, p. 30).

The Chelsea Flower Show was also used by TNZ in 2004, when it commissioned a contemporary garden featuring Maori icons. It was hugely successful, winning a gold award, getting coverage on prime time television and attracting $80 \%$ of Chelsea visitors (TNZ. Pure As; Celebrating 10 Years of 100\% Pure New Zealand, p. 30). To sit alongside this, TNZ papered public transport with $100 \%$ Pure advertisements.

The All Blacks are one of New Zealand's most famous icons and rugby events have been used several times by TNZ to promote New Zealand. In 2005, the Lions tour of New Zealand was used by TNZ to promote the friendliness of New Zealand. A new slogan was created: "make yourself $100 \%$ at home", and fans did find New Zealand a very friendly and welcoming country (TNZ. Pure As; Celebrating 10 Years of 100\% Pure New Zealand, p. 31).

During the 2007 Rugby World Cup in France, TNZ ran a high profile public relations campaign. The key feature was a huge inflatable rugby ball, branded with the $100 \%$ Pure NZ tagline with films on New Zealand being played inside it. The rugby ball was shown in a number of places, including in Paris and Tokyo, to highlight New Zealand's hosting of the 2011 Rugby World Cup. In 2011, TNZ has capitalised on the global media coverage for the 2011 Rugby World Cup as one of the five pillars of its new marketing strategy (TNZ Annual Report 2009/10, p. 7). 
International films are also used by TNZ to promote New Zealand - The Piano showed landscapes here and The Lord of the Rings gave a huge boost to New Zealand's scenic image. These events are also used to showcase New Zealand's talents and allow it to be positioned as a country with innovative technology and wonderful creativity.

More publicity for New Zealand is generated through the International Media Programme (IMP), which works to get writers and journalists to New Zealand. This includes getting shows like Billy Connolly's World Tour of New Zealand, and the American reality show The Bachelor, to be filmed in New Zealand. Writers and journalists with high profiles are also invited here in the hopes that the subsequent coverage will grow New Zealand's image around the world (TNZ. Pure As; Celebrating 10 Years of $100 \%$ Pure New Zealand, p. 33).

\section{Current situation}

In 2007 , the $100 \%$ Pure New Zealand campaign was relaunched with the central idea being New Zealand as the youngest country on earth. The slogan, always accompanied by video or photos of an untouched landscape, is:

"Legend has it that New Zealand was fished from the sea. Fact has it that New

Zealand was the last land mass on earth to be discovered, making New Zealand the youngest country on earth."

The campaign aimed to deal with New Zealand's lack of tradition and history (TNZ. Pure As; Celebrating 10 Years of 100\% Pure New Zealand, p. 50).

The images for this new campaign move away from the landscape and are more centred on the experiences that result from using the landscape - the exhilaration from kayaking, mountain biking and bungy-jumping (TNZ. Pure As; Celebrating 10 Years of 100\% Pure New Zealand, p. 50). A number of other campaigns have been developed in different markets: in China, "Experience New Zealand, Right Now" was launched in April 2009, whereas in Europe, a youth campaign "Go All the Way" was launched in September 2009.

In January 2011, the 100\% Pure New Zealand brand was rebranded as New Zealand $100 \%$ Pure You. The aim is to take the message to the next level, personalising the holiday experience for visitors and making New Zealand more than just "stunning landscape and awesome scenery" (TNZ website, 2011). The scenery will still be an important part of the message, but the emphasis will be on what experiences you can 
have in New Zealand, with the message tailored to strike different chords with different travellers (TNZ website, 2011).

\section{Selecting activities}

TNZ works to maximise tourism by focussing on a number of activities, including building on New Zealand's strong brand and working with domestic and international trade to package and deliver quality products to overseas markets (TNZ, 3 Year Marketing Strategy, p. 2). For example, with the launch of the new brand, TNZ are working with Air New Zealand to ensure all advertisements reflect the new message (TNZ website, 2011).

In March 2010, TNZ developed a new three year marketing strategy. As part of this strategy, TNZ aims to enrich New Zealand's strong brand positioning by "adding a clear message about what you can do in this beautiful place, how easy it is to do it and how much fun you will have" (TNZ, Annual Report, p. 7).

The aim is to keep the $100 \%$ Pure New Zealand tagline as the campaign line but to begin to emphasise the activity aspect of the visitor experience to New Zealand. Visitors will be given a clear view of what they can do in New Zealand and what benefits they can get - that is, how holidaying in New Zealand will make them feel (TNZ 3 Year Marketing Strategy, p. 19). The $100 \%$ Pure New Zealand campaign has successfully created New Zealand as a visually beautiful landscape in people's minds, but now the challenge is to build on this and let people see that it is more than just a lovely film backdrop and untouched landscape.

TNZ will focus investment in selected markets; leverage off digital media to better target audiences and promote New Zealand and build or deepen relationships with private sector companies to help grow the tourist market (TNZ, 3 Year Marketing Strategy, pp 19-21).

Another important part of the TNZ strategy is capitalising on the "visitor bubble and media coverage for RWC 2011” (TNZ 3 Year Marketing Strategy, p. 20). This includes supporting NZ Inc to ensure visitor targets are met and visitors stay longer and spend more (TNZ 3 Year Marketing Strategy, p. 20). 


\section{CONCLUSION}

To have a successful nation brand, a state must create a distinctive image of itself and then actively market the image. New Zealand has created an extremely successful brand and has used this basic tagline brand to market the country as a tourist destination and leverage off this to create a market for other products. After 10 years, New Zealand has recently updated the brand to ensure it is still relevant for purpose.

One of the reasons the brand is doing so well is that it is based on imagery that is core to the New Zealand sense of identity and reflects New Zealanders' strongly held views of themselves. Having a brand that is truly believed in by the population is a great bonus for marketers and is one of the reasons $100 \%$ Pure NZ has been so successful. Tourists, investors and consumers love the images, but they also see that New Zealanders themselves believe the brand and this gives them confidence in it. Its success has been in no small part due to its close association with a central part of New Zealand's national identity.

There are of course problems with relying on landscape, which TNZ has identified and sought to remedy with the New Zealand $100 \%$ You campaign. In terms of tourism, landscape alone cannot sustain a tourist push. For other industries, relying on a landscape that is seen as pure and sustainable is a risk, as if the environment is shown not to be all it is marketed as, a carefully built up reputation is lost. Equally, relying on landscape alone can stop others viewing the nation as anything more than bucolic landscapes - the nation's innovative or technological ability is ignored (Julian Moore in Donaldson, 2006). Canada found this: it relied heavily on the physical landscape to build a brand and the country became associated almost exclusively with those images in people's minds (Mark, 2010, pp 73-74). TNZ has sought to deal with this by emphasising New Zealand as a young country, with its associated synonyms of fresh, innovative and new.

In general, a brand is seen to be successful if it can create an image of itself that produces interest and generates a profitable market. New Zealand has done this. TNZ have worked actively to maintain and sustain the brand, keeping it relevant and fresh. Government agencies have worked with TNZ to leverage off the brand and use it to promote New Zealand's interests off shore. In terms of a co-ordinated approach that has achieved its aim, New Zealand has been extremely successful. 


\section{CHAPTER FOUR \\ DISCUSSION OF CULTURAL DIPLOMACY AND NATION BRANDING IN NEW ZEALAND}

In this chapter New Zealand's cultural diplomacy and nation branding is discussed to see how compatible they are and how they work to help New Zealand meet its obligations and aims as a state and as a nation.

One of the things a state must be able to do if it is to be considered a state is to have the authority and ability to conduct international relations with other states (Evans, 1998, p. 512). In general, because the other attributes of statehood (a permanent population; a defined territory; a government capable of maintaining effective control over its territory) and sovereignty itself can easily be held by states in different degrees, the ability to interact with other states and be recognised by them as a legitimate actor is one of the most important factors in being seen as a state (Evans, 1998, pp 512-13). This gives diplomacy great importance in how states achieve their aims and meet their obligations.

Since the state system emerged in Europe, diplomacy has been a central factor in how states communicate and identify areas of common interest between themselves and others (Evans, 1998, p. 513). Diplomats represent their state and its interests in other states, including the promotion of trade and commercial interests (Evans, 1998, p. 513).

Cultural diplomacy, as a subset of diplomacy, has always had a role to play in this state interaction. It not only showcases a state's achievements, but it also allows for common interests to be found that can serve as the foundations of friendships. By its nature, culture is unthreatening and universal, making it a useful tool for states.

Soft power has always been a useful way for states to persuade others to adopt their viewpoints. The issues that now face the world - terrorism, environmental issues; epidemics, financial instability - are such that many believe public diplomacy will become increasingly more important because it is the most effective way to deal with these problems, and governments need to be collaborating closely with one another and with other actors in the international sphere (Riordan in Gilboa, 2008, p. 69). To collaborate and work together, states need to trust one another and have relationships. Cultural diplomacy provides a useful way to build these relationships. 
New Zealand's aims as a state

New Zealand as a state has a number of obligations and aims. Its foreign policy aims are to advance and protect New Zealand's security and prosperity interests and ensure its voice is heard abroad. In the last few years, MFAT has:

"through its political, economic, multilateral and developmental diplomacy, focused resolutely on the Government's top priority of increasing New Zealand's prosperity to provide better opportunities and security to all New Zealanders."

(MFAT Annual Report 2010, web site)

MFAT does this through a series of outcomes, including safeguarding New Zealand's security and economic interests through its political and security relationships, advancing New Zealand's economic growth by negotiating trade agreements and supporting New Zealand business and enabling the transfer of skills and technology to New Zealand (MFAT Annual Report 2010, web site). In essence, this means maintaining and developing the relationships and influence New Zealand already has, so that foreign policy goals and other objectives can be achieved (MFAT Annual Report 2010, web site).

With these aims, nation branding can very clearly be seen to help achieve New Zealand's aims as a state. It actively works to advance New Zealand's international competitiveness overseas and the $100 \%$ Pure brand adds value to New Zealand businesses, providing them with an instantly recognisable and highly regarded label.

The cultural diplomacy programmes were originally less about promoting economic interests and were more about developing and maintaining long term relationships. Some of these programmes retain that aim but increasingly, along with the promotion of culture goes the desire to further New Zealand's economic interests. Cultural diplomacy may not be as single-minded in serving New Zealand's economic aims as nation branding is, but it is certainly one more weapon in the foreign policy armoury.

\section{Cultural diplomacy}

Cultural diplomacy is the use of a state's soft power resources, and in particular, its arts and culture, to construct and maintain long term relationships with foreign states. It has traditionally been the interaction of officials and governments and it takes a long term, strategic view. 
Increasingly, cultural diplomacy is moving away from this traditional definition and is becoming much more economically focussed. This can reflect the priorities of the government of the day, but what is not evident is what long term implications this has for cultural diplomacy and our future relationships.

Another issue that is becoming increasingly more noticeable in cultural diplomacy is the way states' populations are now the recipient of attention. In the past, interactions were government elite to elite - but the growth in mass media and the increasingly importance of domestic populations in the politics of their nations has meant that cultural diplomacy has had to change to accommodate this new breed of politically-savvy people. This too has implications on cultural diplomacy and future relationships.

\section{Moving away from traditional definitions}

In many ways, it could be argued that cultural diplomacy's modern roots reflect the tensions of the cold war era when two super powers were contending for the hearts and minds of the rest of the world's populations. In those circumstances, selling your state's values and ideology was the central priority and cultural diplomacy could be seen as little more than propaganda in many cases.

For New Zealand, selling the state as an example to be emulated has never been feasible, because it is too so small and isolated and so is unlikely to be seen as a role model. For New Zealand, cultural diplomacy has always had to be practised differently than larger states practise it: it is New Zealand's signature to go against the usual western view (Templeton, 1993, pp 132). This view can be seen in the nuclear free ships policy of the 1980s and New Zealand's refusal to fight with the US in Iraq: New Zealand prides itself on being a free-thinking, independent little state that follows its own values. It does not, however, engage in any kind of diplomacy or propaganda like cultural diplomacy to convince others to follow suit.

New Zealand's image as an independent state with clear values and a distinct identity has always been at the heart of its cultural diplomacy. Showcasing New Zealand culture was seen as the way to make friends and prove to other states how sophisticated and worthy of attention New Zealand was (Corner in Mark, 2008, pp 124-125). Central to it has always been the distinct identity of New Zealand. When New Zealand's Cultural Diplomacy and International Programme was launched in 2004, the press release notes 
spoke of a programme which would "assert a more visible and distinctive national identity for this country" because New Zealand was "a culturally diverse and contemporary nation" and promoting this would "deepen ties with other countries" and "foster understanding in the broader sense". It would "support the growth of creative industries", would "show the world that New Zealand is a unique, culturally diverse and creative nation" and would only as a secondary aim "support and lift the profile of other trade initiatives offshore" (MCH, Information for Press Release on CDIP, 2004).

This message is in direct contrast to the current CDIP, which emphasises the economic values only. Gone are the messages that "economic and cultural successes are mutually important to New Zealand and they go hand in hand" (MCH Information for Press Release on CDIP, 2004). Cultural success in its own right is no longer seen as valid - or at least, certainly not mentioned as being valid. Culture's aim is to promote primarily trade interests.

Mulcahy says cultural diplomacy can be used to fulfil short term political considerations, subordinating long term understanding (Mulcahy, 1999, p. 4). This runs the risk of undoing one of the key goals of cultural diplomacy, which is creating mutual, and long term, understanding between nations. Mark agrees with this, saying cultural diplomacy can also run the risk of reducing culture to an economic commodity (Mark, 2008, p. 61).

It is perhaps inevitable that New Zealand's cultural diplomacy has ended up focussed so heavily on trade. Its isolation and large primary produce markets, and its reliance on tourism, all mean that it needs to market itself heavily and its products to get them into overseas markets, which are often heavily regulated or protected by national interests. New Zealand's government needs to work closely with other government agencies, lobby groups, parliamentary committees and the like to ensure our products can gain a foothold and be sold overseas (Templeton, p. 134). Increasingly too, the populations of overseas countries need to be won over to convince them to buy New Zealand products and to visit New Zealand.

The decision in June 2010, to divert funding from the CDIP to use onshore for activities associated with the Rugby World Cup (DOM (10) 41), showed that New Zealand needs to make the most of all opportunities it can to promote itself. What is interesting, however, is that recently, the trade aims seem to be overwhelming any other aims. The Cabinet paper is explicit that the money would be used to "prioritise flagship events designed to achieve economic benefits for New Zealand", and will "contribute to the 
growth of our international tourism market" (DOM (10) 41, pp 3-4). Increasingly, cultural diplomacy is not a tool to be used to further relationships and tell the country's story - it is merely another way to attract investment.

\section{Communicating with populations}

Traditionally, cultural diplomacy has been conducted government to government, elite to elite but changes in technology and audiences mean this has changed. In many ways the new world suits the shorter, simpler nation branding values, but there is still a place for cultural diplomacy.

Technological changes have affected communication, and diplomatic communication in particular. The advent of the internet and social media and the growth in an activist civil society (Potter, 2002 p. 5) has meant that more effort is now concentrated on communicating directly with foreign publics.

Gilboa says there has been a political revolution, with public opinion increasingly becoming more important (Gilboa, 2008, p. 58). The problem with this is that technology is making cultural diplomacy more difficult as it allows unsubstantiated rumours to run riot. People on the internet are not framed by any ethics and can shape and frame issues as they will, and there is so much material out there now, there is no guarantee the message will be picked up by the target audience (Johnson, 2006, p. 45). The media are also now more invasive in everyday life, affecting the decisions people make about their civic lives (Gilboa, 2008, p. 58), and the spin or slant the media choose to put on things is often less about truth and more about sensationalism.

As well as an increased importance for the media, there has also been a rise in the number of non-state actors (Gilboa, 2008, p. 58), with non-government organisations increasingly playing a role in public/cultural diplomacy (Ross, 2002, p. 76). Private organisations now affect public attitudes and can have a direct influence on a government's foreign policy decisions (Signitzer and Coombs, quoted in Gilboa, 2008, p. 57). Increasingly, if governments want to get their message across and influence events, they need to work through non-government organisations and networks, who have the credibility, expertise and networks that states themselves lack (Leonard, 2002, p. 54).

More people are involved in sending the cultural diplomacy message - because cultural diplomacy could be characterised by interactions of the many to the many (Bound, 2007, 
p. 75), all people now theoretically represent their country, and it is important to educate the citizenry to send a consistent message (Bound, 2007, pp 73-80). Having anyone present the culture of a country can result in an incoherent message - or, in worst case situations, can result in anger or misunderstandings.

Formal cultural diplomacy is still needed to mediate in these situations and provide explanations and translations of one culture to the other (Bound, 2007, p. 19). In a situation where all views are given equal weight and anyone can speak for their state, there is a real need for an official state view, spoken by people who have long standing relationships with other states. Diplomacy is of even more importance now than it ever was, because a single, official voice needs to cut through the babble.

A state has an advantage if others are attracted to its values. The mass communication revolution means that favourable image and reputation has become more important than territory and raw materials - attraction and persuasion have replaced military and economic measures (Gilboa, 2008, p. 56). With a high level of soft power, the state can set the agenda and frame the issues (Fan, 2008, p. 148) and make sure its foreign policy aims are met. Diplomacy does this, but nation branding too is an ideal way of doing this as it deals with only the attractive aspects of a country and presents it in a short, easily digestible and populist way.

The very nature of the internet means that the static cultures we used to live in are changing too and with globalisation comes the need to protect culture (Gilboa, 2008, p. 58). Cultures now mingle and morph into other things (Bound, 2007, p. 19), changing old cultures and creating new hybrids. This has implications for states and their identities and can provide serious challenges to nations who are trying to hold onto their unique identities. In many ways, countries like New Zealand may have an advantage in a world of merging cultures as our whole history is one of different peoples meeting and merging and struggling to create something out of many parts. Multiculturalism may well be a strength in the world we live in today.

How cultural diplomacy works and its overarching message

Currently, New Zealand's cultural diplomacy is a mix of strands: the Cultural Diplomacy International Programme, with its four core agencies and the smaller agencies engaged in elements of soft power such as sport, arts, films, museums. Outside this field, but still 
contributing, are the ministries with specific areas of interest, such as science and education.

An evaluation of the first three years of the CDIP in 2007 showed that the greatest successes for the CDIP had been when the core agencies (MCH, MFAT, NZTE and TNZ) worked together and used an event or series of events to leverage off and involve other firms and agencies (MCH, CDIP Evaluation Report 2007, p. 14). The CDIP's main purpose is to increase understanding of New Zealand's culture and get the attention of a foreign audience: once this has been done, other agencies need to move in and do their thing, be it diplomatic, trade or education (MCH, CDIP Evaluation Report 2007, p. 15). To work well, all the strands need to be working together to make sure every event and every entry for New Zealand is used as effectively and usefully as possible.

Keeping an identity safe is also a role that sub-state actors such as museums and libraries can help in (Bound, 2007, p. 63). These agencies can deal with their overseas counterparts and combat stereotypes and build understandings. In New Zealand's case, a number of cultural agencies, tied to the government, do engage in exchanges and programmes with their overseas counterparts. These programmes, if tied to the cultural message, can help with building trust and relationships.

The core agencies all sit together closely with the nation branding strategy, making for a very cohesive message about New Zealand on the international stage. Interestingly though, having elements that are not integrated - such as the diplomacy for science or the various sports and arts organisations - may make for a stronger cultural diplomacy as, unlike the mainstream cultural diplomacy groups, these smaller strands seem more committed to building relationships and creating trust. Their view is less economic and more strategic and may contribute to, and even soften, the more hardline economic message portrayed by the official CDIP and nation brand.

\section{Nation branding}

Nation branding, unlike cultural diplomacy, is all about marketing and making sure an economic advantage is gained for a product. It does this through communicating its message to the largest possible audience. Szondi argues that this is one of the traditional differences between diplomacy and nation branding: branding targets mass audiences and the general public, while public diplomacy targets well-defined publics such as cultural or political elites, opinion formers and leaders - the elite of a country (Szondi, 
2008, p. 13). A brand needs to capture the imagination of consumers by creating an emotional tie (Morgan, 2002, p. 336) and building a positive image of the nation by using the nation's culture and identity.

The $100 \%$ Pure New Zealand brand has been very successful in achieving this for New Zealand: it has managed to create a distinctive image that has captured the imagination of the world and attract visitors to the country and consumers for our products. It has done this primarily by using a particular iconography that is of importance to New Zealanders themselves, and which can easily be modelled by the population. This is landscape: with the geography of New Zealand providing a strong set of images and associated values for use in tourism. New Zealand's landscape, and the way it has been used, shows a clean, pristine, untouched space. It is full of places to experience solitude and peace; or to take part in adrenaline sports. The landscape symbolises the spirit of the country: pure and exhilarating. The land is "the youngest land on earth", making the people resilient, innovative and flexible. There is space for everyone to be themselves and experience life to the full. The brand has also cleverly taken what was an outdated view of New Zealand with its green fields and sheep, and turned it into a more vibrant, modern image - but still building on the stereotypes that people have of New Zealand as an empty landscape.

This imagery and the values its portrays have since been used to widen the brand and associate the country with a range of products. In a world where being organic and environmentally sustainable is important, New Zealand's image as a clean, green country is invaluable. A range of products can be associated with the values of the tourism brand and thus are accepted by consumers as being of the same value as the $100 \%$ Pure New Zealand brand. As discussed in chapter 3, there are risks associated with this: that if the nation is found not to be clean and green, New Zealand's reputation will be damaged; and, secondly, a nation that is so firmly tied to its landscape may not be seen to be anything other than pretty - it is not innovative, cutting edge or future-forward. New Zealand itself is dealing with these issues as industries and businesses struggle to keep their competitive edge while following sustainable policies. It is a struggle that cannot be allowed to jeopardise the brand, as clean and green is essential to the face New Zealand presents to the world and is the bedrock of its international reputation.

The New Zealand brand has been very successful because it has been one effort, coordinated by TNZ, but used by other agencies. There is no fragmentation of the message and all international activities, including government initiatives, use the brand to market themselves. 
The issue now for the brand is to ensure that it remains recognisable, but continues to grow and remain relevant. TNZ are addressing this issue with the launch of their new brand to position people into the landscapes and emphasise the activities you can do and the emotions you will feel in these landscapes.

The problem with nation branding is that it is a very ubiquitous image that soon begins to encapsulate the entire country. This can result in a number of problems such as regions or groups feeling excluded from the national image or the national image actually changing to reflect the brand. The brand has to reconcile a range of local and regional interests and promote an identity acceptable to a range of constituencies. The point of branding is to erase the internal differentiation, resistance or conflict that characterise a nation's population and present a single, core idea (Aroncyzk 2008, p. 55). New Zealand has managed to avoid this divisive, exclusionary brand as it has concentrated on landscape as the primary brand imagery. Any divisions in society have not been reflected in the brand: landscape is shown as something that all peoples and cultures enjoy. Successful destination branding is about achieving a balance between applying cutting-edge advertising and public relations approaches to a marketing problem and the realpolitik of managing local, regional and national politics (Morgan, 2002, p. 342). In the $100 \%$ Pure New Zealand, and the new New Zealand 100\% Pure You campaign, internal politics have been left out of the brand.

One issue that is applicable to the New Zealand brand though, and which is related to the above point, is that the brand, with is simple message, can change the nature of national identity. New Zealanders have always been aware of the beauty of their landscape, but this beauty has gone hand in hand with an understanding of the danger that the landscape also poses. Art, literature and history are full of examples of how the landscape must be treated with respect because it can kill. The $100 \%$ Pure New Zealand brand, firmly focussed on the beauty of the New Zealand landscape and how accessible it is for all, has taken the danger and wariness aspect of the relationship out of New Zealanders' sense of their place. In some ways, the shock felt by New Zealanders at the Pike River mine disaster and the Christchurch earthquake may be because they have been conditioned to see the landscape as a scenic backdrop to adventure sports, and not an environment that should be respected. This double reminder that the land is not just a marketing advantage for our nation is sobering. 
Aroncyzk runs an interesting argument where she says that nation branding is seen as a public good, inviting participation from all citizens and drawing on nationalist discourse to colour the brand, but the authority for the brand is run by private agencies who benefit from it (Aroncyzk, 2008, p. 43). Because branding a nation advances the interests of the global economic players, increased importance is given to financial markets and money interests, and less to people and culture (Mark, 2008, p. 61). The very fact of privileging collective representation over diverse expression and replacing accountability with facilitation changes the very nature of the culture that informs the brand and affects the moral basis of national citizenship (Aroncyzk, 2008, p. 43). In other words, the conditions that create culture are not compatible with the conditions needed to create and maintain a brand.

A successful brand can transplant the national identity because a nation brand is about economic advantage and not about promoting culture (Mark, 2008, pp 60-61). A country that has strongly internalised its brand - as New Zealand has - may be at risk of losing parts of its culture because it allows only depictions of a marketable nation to be portrayed and does not allow for the conflict and tension that often produces good art. What is good for selling a nation's products abroad is not always good for art and there are criticisms that the $100 \%$ brand has failed to convey New Zealand's culture and society and undersells its Maori and Polynesian cultural heritage (TNZ Baseline Summary p. 19). There is also anecdotal evidence that visitors want to see more about New Zealand's distinctive culture (Donaldson, 2006).

The New Zealand brand has been extremely successful and has easily met the aims of nation branding. It has drawn on an image close to the essence of New Zealanders and built this simple image into a world renowned brand. TNZ have worked with other agencies to leverage off the brand and increase its spread and it has carefully maintained the brand and acted to tweak it when it became old. It has been a big success story for New Zealand.

This is not to say the brand is without problems. The brand rests on a clean, green landscape, and as discussed, the loss of this reputation would severely damage New Zealand's brand. The brand, because of its success, may have also changed the nature of New Zealand identity and the repercussions of this are unknown. The relationship with the land and the growth of culture and the way people view themselves and their regions, may have been altered by the pre-eminence of the brand images in our society. The way in which economic imperatives have been allowed to swamp cultural ones is frightening: 
not only the loss of the conditions to create culture, but also the fact that culture feeds the brand and without a growing, thriving culture, the brand too will wither and die. It is important that, for the brand to continue to grow, some thought must be given to the long term consequences of subverting all to economic benefits.

\section{Conclusion}

The extent to which the cultural diplomacy programme - despite having as a central aim the need to meet economic objectives - manages to convey New Zealand's culture in a way that appeals to others and is not seen as propaganda is interesting. While the aims of the CDIP are quite focussed on achieving some sort of economic value for New Zealand, the message being received by the outside world appears to be heavily influenced by perceptions of New Zealand as a peaceful, friendly, unassuming state. This suggests that the New Zealand identity is strong enough internationally to have already created a view of the country that predisposes people to think favourably about the country. This is in no small part due to the nation branding, but also to a range of factors, including New Zealand's willingness to follow its own values (for example, choosing not to stand alongside those nations that joined the US to fight in Iraq in 2003). New Zealand has managed to build up an international image that it reflects in its domestic and foreign policies, and which is reinforced by a strong and consistent cultural diplomacy and nation brand.

One of the questions this work has raised is whether cultural diplomacy and nation branding serve different purposes. Historically, the answer would have been yes. Cultural diplomacy is all about using culture to build relationships with foreign states, whereas nation branding is using a very simple image to create a market for a nation's products. The two are not incompatible, but they are different.

Today however, the two are growing more closely together. The importance of a strong economy has meant that governments now persuade their people that the national interest is best served if the country can find success economically (Aroncyzk 2008, p. 44). Aronczyk says that, while this is not new, using the national culture to gain a competitive edge over other nations is (Aronczyk 2008, p44). For the first time, there is a need to make national identity "useful" - that is, economically valuable (Aroncyzk, 2009, p. 292). The brand, which is attractive not just to foreigners, but also to New Zealanders, convinces people that their government does have their best interests at heart and is managing to gain economic benefits for New Zealand. Increasingly, there is a tendency 
for the more long term and not so obvious benefits of cultural diplomacy to be jettisoned in favour of what is a highly visible and obvious economic benefit for New Zealand.

In many ways, this is understandable. New Zealand is a small, remote country and to be successful, it needs to be recognised. For New Zealand, sport and film have been successful ways to capture the world's attention. Films like The Piano, Whale Rider and the Lord of the Rings trilogy have caught the world's attention and propelled New Zealand into the spotlight. Hosting large sporting events such as the America's Cup and the Rugby World Cup have gained New Zealand a large audience. The job of cultural diplomacy is to facilitate and capitalise on these (Doole, 2007).

Cultural diplomacy could be said to be the way a nation builds relationships that can then be leveraged off to gain an economic advantage. Thus, after the America's Cup, New Zealand managed to position itself as a world-leader in marine technology and yacht design; similarly, the Lord of the Rings films gave New Zealand a reputation for cutting edge digital work. Both events showcased aspects of New Zealand's culture, but ultimately, both have had large financial spin-offs for the country. It is important that these successes are taken and used to showcase New Zealand technology as a place of cutting edge, innovative technologies and goods - and not just a pretty land of sheep, green fields and volcanic mountains (Doole, 2007)

Aronczyk argues that the nation brand has risen in favour over diplomacy because it is non-threatening: it showcases the country according to inoffensive snippets of culture, history and geography, a "more progressive form of patriotism than its chauvinistic or antagonistic counterparts" (Aronczyk 2009, p. 294). There is truth in this: cultural and public diplomacy can be very similar to propaganda. With a nation brand, nobody is in any doubt what the aim is: it is to get money. The problem is, for many nations, this desire to have their money could be seen to be offensive. In a marketing, private enterprise world, this might be acceptable - but between governments it seems insulting. It almost goes against the point of soft power too: a nation that only cares about getting wealth is not modelling values that will necessarily win the hearts of others.

For this reason, it is important that New Zealand does not lose sight of the importance of traditional cultural diplomacy. Forging and maintaining relationships with other countries is vital, and it needs to be recognised that these relationships do not always have an instant or monetary pay off. As I write this, eight teams (totalling 433 personnel) of foreign search and rescue workers are in Christchurch helping find people buried 
under rubble. Five more teams from different countries are expected in the next few days. This sort of relationship is borne out of years of carefully maintained relationships, where both sides value the friendships they have. An emphasis on economic-only ties would jeopardise all that New Zealand has created and worked for in the past.

We need to be aware that, while a strong economy is important, there are other sorts of relationships that are more valuable. As Julia Gillard said in the New Zealand Parliament on 16 February (Gillard address to NZ Parliament, 2011):

Wherever Australian and New Zealand blood has been shed, it remains sacred ground, sacred because when our young men were sent to far shores, they went not for wealth or gain, but to defend common values and a treasured way of life...These [values] are what ANZAC means... it is a living story ...the ANZAC story speaks for both our nations. An imperishable Trans-Tasman bond ... Australia has many alliances and friendships around the world. Economic and defence partnerships of every kind. But New Zealand alone is family.

New Zealand has a closer relationship to Australia than to other nations, but the point remains: there are relationships between nations that create bonds that are more precious and long lasting than economic benefits. We should not lose sight of this. 


\section{CONCLUSION}

This thesis has looked at cultural diplomacy and nation branding in this dissertation to see how they are practised in the New Zealand context.

The thesis concludes that cultural diplomacy was the way in which a state uses its arts and culture to build and sustain long term relationships with foreign states. It takes a long term view, building relationships that are stable. These relationships grow out of a sharing of culture and identity, making them based on soft power values such as attraction and mutual respect. Public diplomacy, often confused with cultural diplomacy, was also looked at. While the two are alike, and are often interchangeable, the thesis concluded that public diplomacy is about communication with foreign publics, and is concerned with the full range of government interests. Cultural diplomacy, on the other hand, deals only with culture and, traditionally at least, is the communication with other governments and officials.

Nation branding is the way in which a state creates an image of itself for the consumer and then markets this image. Once the brand has been established a nation can use the image and resources to create markets and attract customers. The brand is often created using the national identity, taking specific values and attributes to create reputational capital for the country.

Finally, propaganda was looked briefly. Soft power methods can be seen as propaganda and this could include cultural diplomacy and nation branding. Propaganda is the conscious persuasion of people to accept a particular view of something. Propagandists manipulate factors to gain their desired result. The conclusion arrived at was that, while cultural diplomacy could easily become propaganda, any form of two way communication or dialogue, rather than out and out persuasion, lessens the chances it will be seen by the target state as propaganda. Nation branding, with its symbols and emotional manipulation, is also very close to propaganda, but in the end, it does not seek to change people's minds, simply to get them to buy the product. It is a fine distinction, but the very lack of subtlety or overt political aim of nation branding makes it unlikely people would see it as an insidious form of propaganda.

After looking closely at New Zealand's cultural diplomacy, and in particular at the Cultural Diplomacy and International Programme (CDIP), the thesis concluded that the 
programme meets the definition of cultural diplomacy. The programme does promote understanding of New Zealand's identity and values in other countries and it is based on national identity and our unique culture. The programme does pursue domestic objectives and aims and it does spend some time helping artists and providing opportunities for our unique culture. Finally, it does complement traditional diplomacy.

The thesis findings were interesting however, as they showed that in recent years, cultural diplomacy in New Zealand has been moving away from its traditional definition and is becoming more economically focussed. In fact, it is blurring with nation branding. This could become an issue for New Zealand in the future as relationships built are short term and are usually for some economic gain and may not result in the sort of long term relationships that countries need. This may well have implications for New Zealand's foreign diplomacy as long established and carefully maintained relationships fall by the wayside.

Nation branding has been a big success story for New Zealand. The $100 \%$ Pure New Zealand brand has gained a big share of the overseas market and has been successful in turning a tourism brand to an umbrella brand that effectively markets many New Zealand products. Tourism New Zealand (TNZ) have been able to use the base brand and build on it to keep it fresh and relevant. The success is due in large part to the use of landscape - a very important part of the New Zealand identity. Using something that resonates with all New Zealanders and which forms a foundation for nationhood gives the $100 \%$ Pure New Zealand brand a truthfulness that makes it work with overseas audiences. Add to this a very coherent and organised cross-government approach, and the New Zealand brand has been a big success story for New Zealand. This does not mean that there are no problems with the brand: the assumptions that the brand are based on, such as having a clean green environment, could easily be disproved and then the brand would lose its reputation - but TNZ have done a good job in attempting to deal with any problems and keep the brand up to date and interesting.

Today's world is a very different place to the world of 20 or 50 years ago. Technology has changed the way people communicate and has affected the way in which governments must communicate with their people and with other publics in other states. New ways of building relationships have to be found. In this world, nation branding is a natural fit: its small, pithy messages that instantly capture attention and create a feeling in the audience suit the internet world. 
There is still a place for cultural diplomacy in this new world though. As more and more people across the world become active participants in politics, it is increasingly important that states have an official voice on the world stage. It is also vital that relationships between states endure beyond short term gains.

Cultural diplomacy and nation branding each occupy a different place in soft power forms of diplomacy. States need both to ensure their foreign policy goals and protect New Zealand's interests and advance its political and security relationships. There is a place for both and, despite decreasing budgets, one does not need to crowd out the other. For a small country like New Zealand, creating and keeping good relationships with bigger powers is important. New Zealand has a good international reputation and it needs to keep this. Sharing our identity and our culture is important to our friends, but it is also important to us. By valuing and sharing our culture we keep it and our identity alive. In today's world, this is even more important than it used to be. 


\section{BIBLIOGRAPHY}

Anderson, B. Imagined Communities: Reflections on the Origins and Spread of Nationalism. $3^{\text {rd }}$ edition. London: Verso, 2006

Anholt, Simon. Brand New Justice: How Branding Places and Products Can Help the Developing World. Oxford and Burlington, MA: Elsevier, 2003,2005

Anholt, Simon. Anholt http://simonanholt.blogspot.com/2007/11/first-comments.html Accessed 11 Jan 2011

Anholt, Simon. http://publicdiplomacymagazine.com/nation-branding-propaganda-orstatecraft/. 2009. Accessed 11 Jan 2011

Arndt, Richard T. The First Resort of Kings: American Cultural Diplomacy in the Twentieth Century. Dulles, Va.: Potomac Books, 2005.

Arndt, Richard T. Rebuilding America's Cultural Diplomacy. Foreign Service Journal 2006 (October): 39-43

Aronczyk, Melissa. "Living the Brand": Nationality, Globality and the Identity Strategies of Nation Branding Consultants. International Journal of Communication 2008; 2: 41-65

Arts Industries Policy Forum, the Curb Center at Vanderbilt. Cultural Diplomacy and the National Interest: In Search of a $21^{\text {st }}$-Century Perspective.

http://www.artsmanagement.net/index.php?module $=$ News\&func $=$ display\&sid $=1078$ Last accessed 23 September 2010

Art New Zealand. http://www.art-newzealand.com/Issues31to40/temaori.htm. Accessed 26 January 2011

Atanasov, Peter. Macedonian National Identity: Quantitative Differences between Unitary and Subaltern National Myths and Narratives. Discussion Paper 32 (Dec 2004) - South East Europe Series. London: The Centre for the Study of Global Governance, London School of Economics, 2004 
Ateljevic, Irena, and Doorne, Stephen. Representing New Zealand: Tourism, Imagery and Ideology. Annals of Tourism Research 2002; 29 (3): 648-667

Australia's Public Diplomacy: Building Our Image. Standing Committee on Foreign Affairs, Defence and Trade, August 2007

Barston, R. P. Modern Diplomacy. 2nd ed. London: Longman, 1997

Belanger, Louis. Redefining Cultural Diplomacy: Cultural Security and Foreign Policy in Canada. Political Psychology 1999 (Dec): 20 (4): 677-699

Belich, James and Wevers, Lydia. Understanding New Zealand Cultural Identities. A discussion paper prepared by the Stout Research Centre for New Zealand Studies, Victoria University of Wellington, for the Ministry for Culture and Heritage, 2008

Bianchini, Franco. Thinking Culturally About Place. Place Branding and Public Diplomacy 2007; 3 (4): 280-286

Bound, Kirsten, Rachel Briggs, John and Holden and Samuel Jones. Cultural Diplomacy. London: Demos, 2007

Bolewski, Wilfried. Diplomatic Processes and Cultural Variations: The Relevance of Culture in Diplomacy. The Whitehead Journal of Diplomacy and International Relations 2008 (Winter/Spring). www.journalofdiplomacy.org accessed 19 March 2010

Caute, David. The Dancer Defects: The Struggle for Cultural Supremacy During the Cold War. New York: Oxford University Press, 2003

Clark, Helen. Address to the Friends of the Turnbull Library 2000. 21 September 2000.

Clifton, Jane. Choice, Bro. The Listener 2010 (July 3): 14-18

Country Brand Index 2009 / Executive Summary. FutureBrand, 2010

Cowan, Geoffrey and Cull, Nicholas J. Public Diplomacy in a Changing World. The Annals of the American Academy of Political and Social Science 2008; 616: 6-8 
Creative New Zealand International Strategy. Creative New Zealand 2010.

www.creativenz.govt.nz/assets/.../19/strategic plan_2010-2013 draft.doc?. Accessed February 2011

Cultural Diplomacy and the National Interest: In Search of a $21^{\text {st }}$ Century Perspective. Arts Industries Policy Forum, The Curb Center at Vanderbilt 2006

Cultural Diplomacy: The Linchpin of Public Diplomacy. Report of the Advisory Committee on Cultural Diplomacy, US Department of State, September 2005

Cultural Diplomacy and the United States Government: A Survey http://www.culturalpolicy.org/pdf/MCCpaper.pdf Accessed 19 March 2010

Cultural Diplomacy: recommendations and research. Report of the Center for Arts and Culture. Washington, DC: July 2004.

http://www.culturalpolicy.org/pdf/CulturalDiplomacy.pdf. Last accessed 7 March 2011

Dinnie, Keith. Nation Branding: Concepts, Issues, Practice. Oxford and Burlington, MA: Elsevier, 2008

Donaldson, Rachel Heyler. New Zealand Inc. Marketing Magazine, 2006 (Sunday, October 1). http://www.allbusiness.com/profssional-scientific/advertising-relatedservices/408498-1.html. Accessed 5 July 2010

Doole, Beverley. Tea with the FT: Helen Clark. FT.com Financial Times Columnists February 2007. http://www.ft.com/cms/s/b1b28906-b0f6-11db-b901-

0000779e2340.html. Accessed February 2007

Education New Zealand. Towards 201: Sustainability, Growth, Recognition: An Industry Medium Term Statement of Strategic Intent for International Education 2007201. Education New Zealand: May 2007

Evans, Graham, and Newnham, Jeffrey. Penguin Dictionary of International Relations. Penguin Books: London, New York, 1998 
Fan, Ying. Soft Power: Power of Attraction or Confusion? Place Branding and Public Diplomacy 2008; 4 (2): 147-158

Feigenbaum, Harvey B. Globalization and Cultural Diplomacy. Washington D.C.: Centre for Arts and Culture, 2001. Also available at http://www.culturalpolicy.org/pdf/globalization.pdf

Feigenbaum, HB. Globalization and Cultural Diplomacy. Center for Arts and Culture. Art, Culture and the National Agenda Issue Paper, 2001

Finn, Helena K. The Case for Cultural Diplomacy: Engaging Foreign Audiences. Foreign Affairs 2003; 82 (6): 15-20

Garnham, Nicholas. The Mass Media, Cultural Identity and the Public Sphere in the Modern World. Public Culture 1993; 5: 251-265

Gilboa, Eytan. Searching for a Theory of Public Diplomacy. The Annals of the American Academy of Political and Social Science 2008; 616 (1): 55-77

Gillard, Julia. Address to the Parliament of New Zealand, http://www.pm.gov.au/pressoffice/address-parliament-new-zealand-wellington. Accessed 24 February 2011

Gregory, Bruce. Public Diplomacy and Strategic Communication: Cultures, Firewalls, and Imported Norms. Prepared for presentation at the American Political Science Association Conference on International Communication and Conflict. Washington DC: George Washington University and Georgetown University. August 31, 2005

Gudjonsson, Hlynur. Nation Branding. Place branding 2205; 1 (3): 283-298

Guibernau, Montserrat. Anthony D. Smith on Nations and National Identity: A Critical Assessment. Nations and Nationalism 2004; 10 (1/2): 125-141

Guibernau, Montserrat and Hutchinson, John. History and National Destiny. Nations and Nationalism 2004; 10 (1/2): 1-8

Guibernau, M. The Identity of Nations. Cambridge: Polity Press, 2007 
Hixon, Walter L. Propaganda, Culture and the Cold War. New York: St. Martin's Press, 1996

The International Education Agenda: A Strategy for 2007-2012. New Zealand Government, August 2007

Joffe, Josef. The Perils of Soft Power. The New York Times 14 May 2006.

http://www.nytimes.com/2006/05/14/magazine/14wwln_lede.html? Accessed May 2010

Johnson, Joe. How Does Public Diplomacy Measure Up? Foreign Service Journal 2006 (Oct): 44-52

Kennedy, Liam. Remembering September 11: photography as cultural diplomacy. International Affairs 2003; 79 (2): 315-326

"Kiwis trash nature, says DOC boss, http://www.stuff.co.nz/environment/4209723 accessed 8 October 2010

Leonard, Mark. Diplomacy by Other Means. Foreign Policy 2002 (Sept-Oct); 132: 4856

Lima, Antonio F de. The role of international educational exchanges in public diplomacy. Place Branding and Public Diplomacy 2007 (July); 3 (3): 234-251

Lindsay, Beverley. Integrating International Education and Public Diplomacy: Creative Partnerships or Ingenious Propaganda? Comparative Education Review 1989 (Nov); 33 (4): $423-436$

Liping BU. Educational Exchange and Cultural Diplomacy in the Cold War Journal of American Studies 1999; 33: 393-415

Lodge, Creenagh. Success and Failure: The Brand Stories of Two Countries. Brand Management 2002 (Apr): 9 (4-5): 372-384

Mark, Simon. A Comparative Study of the Cultural Diplomacy of Canada, New Zealand and India. PhD Thesis, University of Auckland, 2008 
Mark, Simon. A Greater Role for Clutral Diplomacy. Discussion papers in Diplomacy. Netherlands Institute of International Relations 'Clingendael', 2009

Mark, Simon. Rethinking Cultural Diplomacy: the Cultural Diplomacy of New Zealand, the Canadian Federation and Quebec. Political Science 2010 (Aug); 62 (1): 62-83

Mead, Hirini Moko. Te Maori in New York. http://www.art-

newzealand.com/issues31to40/temaori.htm Accessed January 2011

Ministry for Culture and Heritage

Changes to the Cultural Diplomacy International Programme. Cabinet paper 10 June 2010. DOM Min (10) 4114 June 2010

- $\quad$ CDIP at a Glance Factsheet. Draft, July 2010

- $\quad$ CDIP Project for NZ2011. Draft MCH paper February 2011

- $\quad$ Cultural Diplomacy International Programme: Further Projects. MCH briefing BR 2009 728: 9 December 2009

- Cultural Diplomacy International Programme: Geographical Focus after 2006/07. Briefing paper BR 2006/532; 24 July 2006

- Cultural Diplomacy International Programme International Programme Information Sheet. January 2008

- $\quad$ Cultural Diplomacy International Programme (CDIP): Review of Performance after Three Years

- $\quad$ Cultural Diplomacy International Programme: Review of 2009-2010. MCH Draft paper, undated paper

- Cultural Diplomacy International Programme: Summary of Paper to Domestic Policy Committee. MCH briefing paper BR 2010/229. 9 June 2010

- $\quad$ Enhancing and Developing Distinctly New Zealand Visitor Experiences and Products with Ihi (the Wow Factor). Draft Report for the Ministry of Culture and Heritage, Aug 2010

GIF Budget Allocation: Cultural Diplomacy International Programme: Policy and NZSO Funding Support. Cabinet Policy Committee POL (04) 119. 25 May 2004

- $\quad$ Growth and Innovation (GIF) Budget Allocation: Cultural Diplomacy International Programme: Policy and New Zealand Symphony Orchestra Funding Support. Cabinet Policy Committee POL Min (04) 12/2. 26 May 2004 
- Information for Press Release on Cultural Diplomacy International Programme. May 2004

- $\quad$ Letter to Martin Matthews, MCH CE from DPMC on the National Identity Theme. 24 October 2006

- $\quad$ MCH. "Cultural Diplomacy International Programme: Priority Region for Years 6 and 7 (2009/10 and 2010/11). Draft briefing BR 2008/286 28 May 2008

- $\quad$ The Place of Culture in New Zealand's International relations: Te Manatu Taonga Ministry for Culture and Heritage: April 2000

- $\quad$ Selecting CDIP's Priority Region And Cultural Activities. MCH Draft, undated paper

Ministry of Education

- $\quad$ The International Education Agenda: A Strategy for 2007-2010.

August 2007

Ministry of Foreign Affairs and Trade

Cultural Diplomacy International Programme Plaza Nueva Zelandia proposal.: http://www.mfat.govt.nz/Foreign-Relations/LatinAmerica/News/0-inauguration-plaza-nueva-zelandia.php. Accessed 1 February 2011

- $\quad$ Email re NZSO, to MM, MCH, June 2010

- $\quad$ MFAT draft briefing November 2007

- Italy/NZ: IVECO-All Blacks Sponsorship. MFAT Unclassified cable, June 2007

- $\quad$ Statement of Intent and Annual report website http://www.mfat.govt.nz/Media-and-publications/Publications/Annualreport/0-outcome-contributions.php\#outThree

Mitchell, J. M. International Cultural Relations. London: Allen \& Unwin, 1986.

Morgan, Nigel, Pritchard, Annette, Piggott, Rachel. New Zealand, 100\% Pure. The Creation of a Powerful Niche Destination Brand. Journal of Brand Management 2002 (Apr); 9 (4-5): 335-354

Mulcahy, Kevin V. Cultural Diplomacy and the Exchange Programs: 1938-1978. Journal of Arts management, Law and Society 1999 (Spring): 29 (1): 7-28 
Mulcahy, Kevin V. Cultural Diplomacy in the Post-Cold War World: Introduction.

Journal of Arts Management, Law, and Society 1999; 29 (1): 3-6

The National Business Review. 7 November 2010: New Zealand Symphony Orchestra takes on Europe: http://www.nbr.co.nz/article/new-zealand-symphony-orchestra-takeseurope-132827. Accessed 1 February 2011

Nathan, Simon. 'Conservation - a history - Voices in the wilderness, 1769-1907', TeAra

- the Encyclopedia of New Zealand.

URL: http://www.TeAra.govt.nz/en/conservation-a-history/3. updated 2-Mar-09

National Party, Arts, Culture and Heritage Policy, 2008

New Zealand Film Commission. Annual Report, 2010.

http://www.nzfilm.co.nz/AboutUs/AnnualReport.aspx. Accessed February 2011

New Zealand Film Commission. Statement of Intent.

http://www.nzfilm.co.nz/AboutUs/SoI.aspx. Accessed February 2011

New Zealand Herald 28 May 2008: http://www.nzherald.co.nz/nuclear-

power/news/article.cfm?c_id $=500837 \&$ objectid $=10512884$. Accessed 16 September 2010

New Zealand History online: Te Maori exhibition opens in New York. NZ History.net.nz

October 2009/ http://www.nzhistory.net/timeline/10/09 Accessed January 2011

New Zealand History online: New Zealand Timeline.

http://www.nzhistory.net.nz/timeline/10/09. Accessed 26 January 2011

New Frontiers in Science Diplomacy: Navigating the changing balance of power. The Royal Society: January 2010

Noya, Javier. The Symbolic Power of Nations. Place Branding 2005; 2 (1): 53-67

Nye, Joseph S. "Propaganda Isn't the Way: Soft Power." The International Herald Tribune, January 10, 2003.

http://www.ksg.harvard.edu/news/opeds/2003/nye_soft_power_iht_011003.htm 
Nye, Joseph S.. Soft Power. The Means to Success in World Politics. New York: Public Affairs, 2004

Nye, Joseph S.. The Decline of America's Soft Power. Foreign Affairs 2004; 83 (3): 1620

Nye, Joseph. Public Diplomacy and Soft Power. The Annals of the American Academy of Political and Social Science 2008; 616 (1); 94-109

'NZ's pure image rotting”, http://www.stuff.co.nz/3852029/ accessed 25 June 2010

NZSO News. http://www.nzso.co.nz/news_and_media/broadcasts_reviews Accessed 28 January 2011

O'Shaughnessy, John and O'Shaughnessy, Nicholas J. Treating the Nation as a Brand; Some Neglected Issues. Journal of Macromarketing 2000 (June): 20 (1): 56-64

“100\% Pure NZ, but are we?” http://TVNZ.co.nz/national-news/ accessed 27 September 2010

Pawson, Eric. Branding Strategies and Languages of Consumption. New Zealand Geographer 1997; 53 (2): 16-20

Potter, Evan H. Canada and the New Public Diplomacy. Discussion Papers in Diplomacy. Netherlands Institute of International Relations 'Clingendael', 2002

Report of the Center for Arts and Culture. Cultural Diplomacy: recommendations and research. . Washington, DC: July 2004.

http://www.culturalpolicy.org/pdf/CulturalDiplomacy.pdf. Last accessed 3 June 2010

Ross, Christopher. Public Diplomacy Comes of Age. The Washington Quarterly 2002 (Spring); 25 (2): 75-83

The Royal Society. New Frontiers in Science Diplomacy: Navigating the Changing Balance of Power. London: The Royal Society, January 2010 
Ryniejska-Kieldanowicz, Marta. Cultural Diplomacy as a Form of International Communication. Finalist paper, Institute for Public Relations BledCom Special Prize, 2005. www.instituteforpr.org. Accessed April 2010

Schneider, Cynthia P. 'Culture Communicates: US Diplomacy That Works.' In The New Public Diplomacy. Soft Power in International Relations, edited by Jan Melissen, 147168. Basingstoke: Palgrave, 2005

Schneider, Cynthia P. Culture Communicates: US Diplomacy That Works. Netherlands Institute of International relations 'Clingendael': Sept 2004, no 94

Schneider, Cynthia P. Cultural Diplomacy: Hard to Define, but You'd Know It If You Saw It. Brown Journal of World Affairs 2006-7 (Fall/Winter); 13 (191)

Schneider, Cynthia P. Diplomacy That Works: 'Best Practices' in Cultural Diplomacy. Cultural Diplomacy Research Series: Center for Arts and Culture, 2003

Sherman, Daniel J. and Irit Rogoff (eds). Museum Culture: Histories Discourses Spectacles. London, 1994

(Part 13: Selling Nations: International Exhibitions and Cultural Diplomacy, Brian Wallis)

Skinner, Heather and Kubacki, Krzysztof. Unravelling the Complex Relationship Between Nationhood, National and Cultural Identity, and Place Branding. Place Branding and Public Diplomacy 2007; 3 (4): 305-316

Smith, A. The Ethnic Origins of Nations. Oxford: Wiley-Blackwell Press, 2009

Smith, Anthony D. National Identity. Reno: University of Nevada Press, 1993

Smith, A. D. Nations and their Pasts. The Nation: Real or Imagined? The 1995 Warwick Debates on Nationalism, 24 October 1995.

http://gellnerpage.tripod.com/Warwick.html . Accessed 18 August 2010

Smith A.D. When is a Nation? Geopolitics 2002; 7 (2): 5-32 
Smyth, Rosaleen. Mapping US Diplomacy in the $21^{\text {st }}$ Century. Australian Journal of International Affairs 2001; 55 (3): 421-44

Snow, Nancy. International Exchanges and the U.S. Image. The Annals of the American Academy of Political and Social Science 2008; 616: 198-222

Söllter, Arpad A. The Renaissance of Soft Power. Rediscovering Cultural Diplomacy in Transatlantic Perspective.

http://www.culturaldiplomacy.org/canadameetsgermany/content/articles/programarchive/2008/Renaissance_of_Soft_Power.pdf Accessed 19 March 2010

Stock, Felix. Identity, Image and Brand: A Conceptual Framework. Place Branding and Public Diplomacy 2009; 5 (2): 118-125

Szondi, Gyorgy. Public Diplomacy and Nation Branding: Conceptual Similarities and Differences. Discussion Papers in Diplomacy: Netherlands Institute of International Relations 'Clingendael': 2008

Te Ahukaramu, Charles Royal. Decline and revival. Te Ara - The Enclyclopedia of New Zealand. Updates 3 March 20019. http://www.teara.govt.nz/en/maori/4 Accessed February 2011

Telles Ribeiro, Edgard. Cultural Diplomacy: An Instrument of Foreign Policy. SIFA Ambassador Talks Program, Ministry of Foreign Affairs, Bangkok, Dec 2008. http://www.sifa.in.th/upload/CULTURAL\%20DIPLOMACY.pdf Accessed May 2010.

Templeton, Malcolm (ed). An Eye, an Ear and a Voice: 50 Years in New Zealand's External relations 1943-1993. Wellington: Ministry of Foreign Affairs and Trade Manatu Aorere, 1993

Te Papa Tongarewa. Annual Report.

http://www.tepapa.govt.nz/AboutUs/Pages/Legislationandaccountability.aspx. Accessed January 2011

Te Papa Tongarewa. Statement of Intent. http://www.tepapa.govt.nz/AboutUs/Pages/Legislationandaccountability.aspx. Accessed January 2011 
Tourism New Zealand Manaakitanga Aotearoa. Pure As; Celebrating 10 Years of 100\% Pure New Zealand.

http://www.tourismnewzealand.com/media/106877/10\%20year\%20anniversary\%20of $\%$ 20100\%20\%20pure\%20new\%20zealand\%20campaign \%20-

\%20pure\%20as\%20magazine.pdf. Accessed 15 September 2010

Tourism New Zealand. 3 year marketing strategy.

http://www.tourismnewzealand.com/media/284616/public\%203\%20year\%20market $\% 20$ strategy\%20march\%202010.pdf Last Accessed 23 March 2011

Tourism New Zealand. Website. http://www.tourismnewzealand.com/campaigns/ Last accessed 8 March 2011

Tourism New Zealand 100\% Pure New Zealand. 100\% Pure New Zealand: What We're Doing Out There. http://www.tourismnewzeaalnd.com/campaigns/consumermarketing/the-youngest-country. Accessed 5 July 2010

Tourism New Zealand 100\% Pure New Zealand. 100\% Pure New Zealand: Website $100 \%$ Pure NZ facts and figures.

http://10yearsyoung.tourismnewzealand.com/files/10\%20year\%20anniversary $\% 20$ of $\% 20$ 100\%20Pure\%20New\%20Zealand\%20campaign\%20-\%20Fact\%20Sheet.pdf. Accessed 28 September 2010

Tourism New Zealand New Zealand 100\% Pure You: What we're doing out there. http://www.tourismnewzealand.com/campaigns/ Last accessed 8 March 2011).

True, Jacqui. Globalisation and Identity. In: Miller, Raymond. New Zealand Politics and Government. $4^{\text {th }}$ ed. Oxford University Press: Melbourne, 2006

Urban, Greg. Culture's Public Face. Public Culture 1993; 5: 213-238

Van Ham, Peter. Place Branding: The State of the Art. The Annals of the American Academy of Political and Social Science 2008; 616: 126-149

Vaughan, James R. `A certain Idea of Britain’: British Cultural Diplomacy in the Middle East, 1945-57. Contemporary British History 2005 (June): 19 (2): 151-168 
Vickers, Rhiannon. The New Public Diplomacy: Britain and Canada Compared.

Political Studies Association 2004; 6: 182-194

Waitt, Gordon. Selling Paradise and Adventure: Representations of Landscape in the Tourist Advertising of Australia. Australian Geographical Studies 1997 (Apr): 35 (1): 47-60

Williams, Daniel R. Personal and Social Meanings of Wilderness: Constructing and Contesting Places in a Global Village. USDA Forest Service Proceedings RMRS-P-14 2000. http://www.fs.fed.us/rm/pubs/rmrs_p014/rmrs_p014_077_082.pdf Accessed 8 October 2010

Wang, Jian. Managing National Reputation and International Relations in the Global Era: Public Diplomacy Revisited. Public Relations Review 2006 (June); 32 (2): 91-96

Ward, Tony. Sport and National Identity. Soccer and Society 2009 (Sept); 10 (5): 518531

Wilson, Ernest J. III. Hard Power, Soft Power, Smart Power. The Annals of the American Academy of Political and Social Science 2008; 616: 110-124

Wiseman, Geoffrey. “"Polylateralism' and New Modes of Global Dialogue.” In Diplomacy. Edited by Christer Jönsson and Richard Langhorne, vol. 3, chap. 9. Sage Library of International Relations. London: Sage Publications, 2004

Wiseman, Geoffrey. Pax Americana: Bumping into Diplomatic Culture. International Studies Perspectives 6, no. 4 (2005): 409-430

Wyszomirski, Margaret. International Cultural Relations: A Multi-Country Comparison. Washington, D.C.: Centre for Arts and Culture, 2003

Xifra, Jordi. Building Countries' Overseas Identity and Reputation: A Case Study of Public Paradiplomacy. American Behavioural Scientists 2009; 53: 504-515 